\title{
Cholesterol and Its Metabolites in Tumor Growth: Therapeutic Potential of Statins in Cancer Treatment
}

\section{OPEN ACCESS}

Edited by:

Gabriella Castoria

Università degli Studi della Campania Luigi Vanvitelli Naples, Italy

Reviewed by:

Erika Di Zazzo,

Università degli Studi della Campania

Luigi Vanvitelli Caserta, Italy Maria Marino,

Università degli Studi Roma Tre, Italy Pia Giovannelli,

Università degli Studi della Campania

Luigi Vanvitelli, Italy

*Correspondence:

Rosa Sirianni

rosa.sirianni@unical.it

${ }^{+}$Co-first authors

${ }^{\ddagger}$ Co-last authors

Specialty section:

This article was submitted to Cancer Endocrinology,

a section of the journal

Frontiers in Endocrinology

Received: 19 September 2018 Accepted: 21 December 2018

Published: 21 January 2019

Citation:

Chimento A, Casaburi I, Avena P,

Trotta F, De Luca A, Rago V, Pezzi V and Sirianni R (2019) Cholesterol and

Its Metabolites in Tumor Growth:

Therapeutic Potential of Statins in

Cancer Treatment.

Front. Endocrinol. 9:807.

do: 10.3389/fendo.2018.00807

\author{
Adele Chimento ${ }^{\dagger}$, Ivan Casaburi ${ }^{\dagger}$, Paola Avena, Francesca Trotta, Arianna De Luca, \\ Vittoria Rago, Vincenzo Pezzi ${ }^{\ddagger}$ and Rosa Sirianni ${ }^{* \neq}$
}

Department of Pharmacy and Health and Nutritional Sciences, University of Calabria, Cosenza, Italy

Cholesterol is essential for cell function and viability. It is a component of the plasma membrane and lipid rafts and is a precursor for bile acids, steroid hormones, and Vitamin D. As a ligand for estrogen-related receptor alpha (ESRRA), cholesterol becomes a signaling molecule. Furthermore, cholesterol-derived oxysterols activate liver $X$ receptors (LXRs) or estrogen receptors (ERs). Several studies performed in cancer cells reveal that cholesterol synthesis is enhanced compared to normal cells. Additionally, high serum cholesterol levels are associated with increased risk for many cancers, but thus far, clinical trials with 3-hydroxy-3-methylglutaryl coenzyme A (HMG-CoA) reductase inhibitors (statins) have had mixed results. Statins inhibit cholesterol synthesis within cells through the inhibition of HMG-CoA reductase, the rate-limiting enzyme in the mevalonate and cholesterol synthetic pathway. Many downstream products of mevalonate have a role in cell proliferation, since they are required for maintenance of membrane integrity; signaling, as some proteins to be active must undergo prenylation; protein synthesis, as isopentenyladenine is an essential substrate for the modification of certain tRNAs; and cell-cycle progression. In this review starting from recent acquired findings on the role that cholesterol and its metabolites fulfill in the contest of cancer cells, we discuss the results of studies focused to investigate the use of statins in order to prevent cancer growth and metastasis.

\section{Keywords: cholesterol, statins, cancer treatment, lipid raft, oxysterols, steroids, vitamin D, ERRalpha}

\section{INTRODUCTION}

Cholesterol homeostasis is required for the normal growth of eukaryotic cells. Cholesterol is needed within cell membranes where it regulates membrane fluidity, signaling initiation, and cell adhesion to the extracellular matrix (1). In mammals, cholesterol is a precursor for bile acid and steroid hormone synthesis, cholesterol can be derived from food or synthesized de novo by specialized cells. The low-density lipoprotein (LDL) receptor (LDLR) is the primary pathway for removal of cholesterol from the circulation (2) and its activity is accurately controlled by intracellular cholesterol levels (3). The biosynthetic pathway of cholesterol is highly conserved, from yeast to humans. In the mitochondria, citrate, derived from the tricarboxylic acid (TCA) cycle, is converted to acetyl-coenzyme A (acetyl-CoA) beginning cholesterol synthesis. In the endoplasmic reticulum, acetyl-CoA is converted to lanosterol through a cascade of enzymatic reactions known as the mevalonate pathway. This series of reactions is regulated by a rate-limiting step catalyzed by 3-hydroxy-3-methylglutaryl-coenzyme A (HMG-CoA) reductase, which converts 
HMG-CoA to mevalonate. Downstream products of mevalonate, include cholesterol, ubiquinone, dolichol, and the isoprenoids geranylgeranyl pyrophosphate (GGPP) and farnesyl pyrophosphate (FPP) that bind to several small GTP-binding proteins such as Ras and Rho. Protein prenylation facilitates protein translocation from the cytosol to the membrane, promoting protein-protein and protein-membrane interactions and regulating protein function (4).

Several studies reported that cholesterol plays critical roles in the progression of numerous cancers (5), suggesting how cholesterol accumulation represents another general feature of tumors. HMG-CoA reductase and LDL receptor activities are increased in proliferating cancer cells, causing a rise in cholesterol content and consumption $(6,7)$. Cholesterol synthesis is under feedback control $(8,9)$, which is operated at the level of mevalonic acid production (10-12). When exogenous cholesterol is not available, the synthesis of mevalonate is increased in order to maintain levels of cholesterol and isoprenoids. When exogenous cholesterol levels are elevated a negative feedback mechanism inhibits the synthesis of mevalonic acid (10-12), this is particularly true for the liver (9), but in some species (13) for all tissues, blocking the overall de novo synthesis of endogenous cholesterol. In malignant cells this feedback mechanism is lost (10).

Statins are cholesterol-lowering drugs, which inhibit the rate-limiting step of conversion of HMG-CoA to mevalonate (14). Statins can be differentiated into two types, based on their solubility: hydrophilic (pravastatin, rosuvastatin) and lipophilic (simvastatin, lovastatin, fluvastatin, atorvastatin) statins. Several reports propose a promising role for statins in cancer treatment (15). Observational studies have tried to evaluate the effect of statins on patients with several cancer types such as prostate (16), colorectal $(17,18)$, renal cell carcinoma (19), breast (20), ovarian (21), and lymphoma (22). Results are variable, with some studies suggesting longer survival, and others reporting no benefit. Epidemiological evidences are also variable, depending on the cancer particular type as well as on the statin class used (23). Several data suggest that lipophilic statins may be preferable over the hydrophilic ones as anticancer agents (24). Statins anticancer properties could be explained through their pleiotropic effects such as lowering protein prenylation (17), reducing tumor cell proliferation and migration (20, 25), inhibiting Ras signaling (26) inducing apoptosis through inactivation of Akt and down-regulation of mammalian target of rapamycin (mTOR) (27).

Statins can interfere with cholesterol activities, which include:

- signal molecule on membrane rafts;

- substrate for steroids, oxysterols and Vitamin D3 synthesis;

- ligand for estrogen-related receptor alpha $(\mathrm{ERR} \alpha)$.

In this review, we will discuss the results of studies focused on the use of statins to the purpose of interfering with cholesterol activities, in order to prevent cancer growth and metastasis.

\section{CHOLESTEROL AS SIGNAL MOLECULE ON MEMBRANE RAFTS}

Cholesterol can act as a signaling molecule at the membrane rafts (28). It is well established that cholesterol-rich microdomains in the plasma membrane and lipid rafts constitute centers of organization for signal transduction and intracellular transport (29). Rafts are small functional areas of the plasma membrane, rich in sphingolipids and cholesterol. These regions are fluid but more ordered and tightly packed than the surrounding bilayer, because of saturated fatty acids. Rafts and related membrane microdomains, such as caveolae characterized by high caveolin-1 expression, have been proposed to play important roles in sorting of membrane molecules and in signal transduction in animal cells (30). Glycophosphatidylinositol-anchored (GPI-anchored) proteins; doubly acylated proteins, such as tyrosine kinases of the Src family, $\mathrm{G} \alpha$ subunits of heterotrimeric $\mathrm{G}$ proteins, endothelial nitric oxide synthase (eNOS), and cholesterol-linked and palmitate-anchored proteins are examples of molecules that can be found at membrane rafts (31).

Growth factors signaling are often deregulated in cancer cells. Insulin-like growth factor-I (IGF-I) through its receptor (IGF1R) is one of the most potent natural activators of the phosphatidylinositol 3-kinase (PI3K) and its downstream target Akt, which participate in cell survival pathway. The $\mathrm{PI} 3 \mathrm{~K} / \mathrm{Akt}$ pathway is compartmentalized within plasma membrane raft domains (32). Activated PI3K/Akt control of cell proliferation, apoptosis and tumorogenesis, and aberrant activation of PI3K/Akt pathway contributes to the development and invasiveness of cancer cells $(33,34)$.

Other studies suggest that, within lipid rafts localize both epidermal growth factor receptor (EGFR) and Human Epidermal growth factor Receptor 2 (HER2) and their signaling events are dependent on cholesterol content of the lipid-rafts (35). Once again, the disruption of the lipid rafts, via depletion of circulating cholesterol levels, interferes with the receptor activation, inhibiting cell growth and development (35-37).

Metastatic events are characterized by cell adhesion decrease and cell migration promotion. Integrins and cell surface glycoproteins such as CD44, have a central role in adhesion mechanisms. CD44 is an adhesion molecule associated with lipid rafts and expressed in several cancers $(38,39)$. It has been demonstrated that ligand-binding ability of CD44 to hyaluronan, is governed by its cholesterol-dependent localization to cell membrane microdomains (40).

Several cancer cell types, including breast and prostate, have higher membrane cholesterol levels and are richer in membrane rafts (probably as a result of cholesterol accumulation) than their normal counterparts. For this reason, cholesterol-depleting agents are more effective in inducing apoptosis on these cancer cells than on normal cells $(41,42)$. Rafts/caveolae are rich in various signaling molecules and they have been associated with a number of functions, including cell survival, proliferation, and migration $(28,43)$.

It has been reported that apoptotic pathways, both extrinsic (death receptor pathway) and intrinsic (mitochondrial), are 
associated with lipid rafts because changes in cholesterol content within specific membrane regions regulate apoptotic signaling events $(41,44)$. Signalings from death receptors Fas receptor (FasR) and TNF-related apoptosis-inducing ligand (TRAIL) receptors 1 and 2 are strictly dependent on translocation into lipid rafts $(44,45)$. In fact, TRAIL- and Fas-mediated apoptosis is down-regulated by lowering membrane cholesterol in non-small cell lung carcinoma (46) and human Jurkat T leukemia cells (44).

Very recently, disruption of lipid rafts on breast cancer (BC) cell lines MDA-MB231 and MDA-MB468, using the cholesterol depleting agent methyl- $\beta$-cyclodextrin, resulted in reduced proliferation and migration, induction of apoptosis evidenced by cell shrinkage, membrane blebbing, nuclear condensation, and chromatin cleavage (47). It was already demonstrated for BC, that lipid rafts disruption causes decreased migration and invasion downregulating caveolin-1 along with urokinase-type plasminogen activator receptor (uPAR) and matrix metallopeptidase 9 (MMP-9) (48). In general, proteins identified in cancer lipid rafts include those involved in endocytosis, Src signaling, cytoskeletal remodeling, chaperones, extracellular matrix (ECM) remodeling (49).

\section{Statins and Lipid Rafts}

Based on the importance of cholesterol at the raft/caveola, cholesterol depletion from the plasma membrane would disrupt intracellular signaling triggered by cell surface receptors (50). Statins lower cellular cholesterol content and thus are useful in the analysis of lipid-raft function. However, the effect on raft/caveola formation in cancer cells after statins treatment are not completely defined.

Menter et al. (51), evidenced that simvastatin inhibited the growth of several tumor cell lines with a time-dependent behavior. A significant reduction in cellular cholesterol level were observed after simvastatin treatment, starting at $24 \mathrm{~h}$ and up to $72 \mathrm{~h}$. During this time frame, authors observed a reduction in cholesterol content at membrane rafts, caveolin1 phosphorylation inhibition, disruption of caveolae and loss of membrane integrity. However, cholesterol depletion affected membrane signaling also in caveolin-negative cells (52). Specifically, using the prostate cancer (PCa) cells LNCaP, which do not express caveolin, simvastatin lowered raft cholesterol content, inhibited Akt signaling and induced apoptosis. In addition, using the same cells grown as xenografts, authors demonstrated that elevation of circulating cholesterol using a cholesterol enriched diet, promoted tumor growth and survival, as a consequence of activated Akt signaling via cholesterol-rich lipid rafts (52).

In another study, four head-and-neck squamous cell carcinomas (HNSCCs), four cervical carcinomas, five non small cell lung cancers (NSCLCs), four colon carcinomas, the epidermoid carcinoma cell line A431, and the breast adenocarcinoma MCF-7 were treated with lipophilic lovastatin, which inhibited EGF-induced EGFR autophosphorylation and its downstream signaling cascades (53).

Similarly, another hydrophobic statin, simvastatin caused in A431 cell line anoikis-like apoptosis, characterized by decreased raft levels, Bcl-xL down-regulation, caspase-3 activation, and Akt inactivation (41).

In PC-3 cells simvastatin treatment down-regulated IGF1R expression (54) and inhibited both basal and IGF-1-induced ERK and Akt activation (55). Raft modulating agents are more effective in cells containing a higher content of lipid rafts. In fact, breast (MCF-7, MDA-MB231) and prostate (PC-3, LNCaP) cancer cell lines were more sensitive to cholesterol depletioninduced cell death than normal breast and prostate cell lines (MCF-10A and PZ-HPV7, respectively) (41).

Garnett et al. examined the effects of $\mathrm{M} \beta \mathrm{CD}$ and the hydrophilic paravastatin on cholesterol-rich rafts and caveolae and on gene transcription in MDA-MB231 and CaLu-1, lung adenocarcinoma. Both treatments caused a downregulation of genes involved in signal transduction, chemokine and antiapoptotic pathways. Pravastatin increased expression of caveolin1, but caveolae density was decreased, because of caveolin-1 inability to properly complex with cholesterol in an altered sterol environment. Similarly, M $\beta C D$ caused an increase in caveolin1 expression and reduced both rafts and caveolae, however, it had less effects on gene transcription. Indeed, signaling are more profoundly affected by statins than by the cholesterolsequestering drug, indicating that not only cholesterol but also some intermediates of cholesterol synthesis downstream of mevalonate, play an important role in signaling pathways at the caveolae (56).

It has been reported that primary cells, HEL, SET-2, and UKE-1, derived from myeloproliferative neoplasms (MPNs) patients require mutated Janus kinase 2 (JAK2), responsible for increased growth signaling $(57,58)$. Simvastatin disrupts lipid raft and has a negative effect on mutated JAK2-dependent signaling. More specifically, in MPNs cells, simvastatin, lovastatin and atorvastatin inhibited mutated JAK2 localization to lipid rafts reducing cell viability, inducing apoptosis and inhibiting colony formation (59). Colony formation assay is considered a $3 \mathrm{D}$ cell culture assay where cells grow independently of a substrate (it is also known as anchorage-independent growth). This assay is particularly useful when studying long-term effects of drugs on anchorage-independent growth of cancer cells. Colony formation evaluates the ability of tumor cells, escaped from the primary tumor site, to exit the blood flow and initiate the post-intravasation phases of metastasis. CD44, as adhesion molecule, plays a central role in the progression of metastasis. The modulation of cholesterol either by statin or M $\beta C D$ causes dissociation of CD44 from the lipid rafts (40) suggesting that membrane cholesterol may impact metastasis formation. Similar to the results on CD44 cholesterol depletion triggers the shedding of several molecules involved in cancer cell adhesion, including CD30 (60), L1-CAM (61) and collagen types XVII (62) and XXIII (63).

Activity of Ras-Related C3 Botulinum Toxin Substrate 1 (Rac1), a member of the Rho family of Small GTPase, is dependent upon its localization in membrane rafts and its activation is correlated with invasion and metastasis. Cholangiocarcinoma cells treated with simvastatin lose Racl rafts localization, because of decreased total cellular cholesterol and disruption of membrane rafts. In normal human cholangiocytes, 
simvastatin reduced cholesterol level, but did not affect Rac1 localization. In addition, simvastatin inhibited cell proliferation but, differently from cancer cells, it did not lead to apoptosis (64).

All these data unequivocally suggest that statins have a direct impact on membrane rafts, reducing signaling transduction and adhesion mechanisms in several cancer cell types, thus interfering with cell proliferation and metastasis.

\section{CHOLESTEROL AS SUBSTRATE FOR STEROIDS AND OXYSTEROLS SYNTHESIS}

Steroid hormones are synthesized from cholesterol in gonads, adrenal cells and placenta (65). The de novo synthesis of some steroid hormones occurs also in the nervous system $(66,67)$, in cardiac tissue (68) and other peripheral sites (69).

Based on their physiological function, steroid hormones are divided into five groups: mineralocorticoids, which act on the kidney to retain sodium; glucocorticoids, involved in the regulation of glucose metabolism; estrogens, which induce female secondary sexual traits; progestins, which are essential for reproduction; and androgens, which induce male secondary sexual characteristics. These classes of hormones contain the cyclopenta-phenanthrene nucleus and arise from reactions catalyzed by enzymes that belong mainly to the family of cytochrome P450 (CYP). They bind to specific steroid hormone receptors, which act as transcription factors. The active hormone/receptor complexes regulate transcription of distinct set of genes in a tissue-specific manner.

Oxysterols represent 27 carbon-atom molecules derived from cholesterol oxidization through enzymatic processes, or byproducts of the cholesterol biosynthetic pathway. Considering the shorter biologic half-life when compared to cholesterol, oxysterols can be considered a way to route cholesterol for catabolism. Specific CYP, localized within the mitochondria or endoplasmic reticulum, are responsible for oxysterol synthesis $(70,71)$. Among them, the most abundant in human serum are $27,24(\mathrm{~S}), 7 \alpha$, and $4 \beta$ hydroxycholesterol (HC). The $24(\mathrm{~S}) \mathrm{HC}$ is synthesized by cholesterol hydroxylase encoded by CYP46A1 in neurons of the central nervous system (72). $7 \alpha$ and $27 \mathrm{HC}$ are synthesized in the liver by CYP7A1 and CYP27A1, and represent, respectively, the first intermediates of classic and acidic bile acid synthetic pathways (73). However, 27HC and its synthesizing enzyme CYP27A1 are found also in other cell types (74). Lastly, $4 \beta \mathrm{HC}$ is generated by CYP3A4, a hepatic drug metabolizing enzyme.

Oxysterols act as ligands of Liver X Receptors (LXR) $\alpha$ (NR1H3) and $\beta$ (NR1H2) (75) to regulate transcription of specific genes. LXR $\alpha$ is expressed primarily in liver, intestine, adipose tissue and macrophages (76), and adrenal (77), whereas LXR $\beta$ is expressed in many cell types (78).

LXR $\alpha$ is also involved in the regulation of the adenosine triphosphate-binding cassette $(\mathrm{ABC})$ proteins $\mathrm{A} 1$ and $\mathrm{G} 1$, cholesterol transporters involved in the flux of cholesterol from enterocytes and macrophages, respectively (79-82). LXRs also seem to have a role in the regulation of human cholesterol ester transfer protein (CETP), which translocates cholesterol esters between lipoproteins (83). Either steroid hormones or oxysterols activate proliferative and metastatic pathways in cancer cells.

\section{Steroid Dependent-Cancer Growth and Progression}

It is well known that estrogens exert their biological effects interacting with two members of the nuclear receptor (NR) family, estrogen receptor $\alpha(\mathrm{ER} \alpha)$ or estrogen receptor $\beta(\mathrm{ER} \beta)$ (84) and with a G-protein coupled receptor namely GPER (85). All three receptors can act at the cell membrane to activate signaling transduction pathways that ultimately regulate gene expression (rapid signaling). Additionally, $\operatorname{ER} \alpha$ and $\operatorname{ER} \beta$ can bind promoter regions of target genes, modulating their transcription (nuclear action). They directly bind DNA at estrogen response elements (EREs) located within promoters of estrogen-regulated target genes. Alternatively, they indirectly bind DNA through the interaction with transcription factors (TFs) that directly bind gene promoters. These TFs are stimulating protein 1 (Sp1) (86), activator protein (AP)-1 (87), nuclear factor- $\kappa \mathrm{B}(\mathrm{NF}-\kappa \mathrm{B})$ (88). The oncogenic role of estrogens is well characterized in carcinomas of hormone-sensitive tissues including breast, prostate, endometrium and ovary, as well as in non-classical estrogen target tissues such as, adrenal, colon, and lung (89).

Genes involved in cell survival and proliferation and regulated by ERs, through direct or indirect binding to DNA, include myelocytomatosis viral oncogene homolog (MYC), cyclin D1 (CCND1), member RAS oncogene family 17 (RAB17), eukaryotic translation initiation factor 3 subunit A (EIF3A), and tumor protein D52-like 1 (TPD52L1) (90-92). Additionally, membrane ERs engage a functional crosstalk with growth factor receptors, including epidermal growth factor receptor (EGFR), insulin receptor (IR), insulin-like growth factor receptor (IGFR). Growth factor signaling can activate $\mathrm{ER} \alpha$ in a ligand independent fashion through phosphorylation, and at the same time, estrogens can regulate IGF signaling (93). Treatment of $\mathrm{ER} \alpha$ positive $\mathrm{BC}$ with selective estrogen receptor modulators (SERMs) such as tamoxifen, often leads to resistance. EGFR and/or IGFR are critical for the resistance to endocrine therapies (94). Additionally, transactivation of EGFR has been observed in MCF7 breast cancer cells via tamoxifen-dependent activation of GPER (95). The use of tamoxifen on patients with initial GPERpositive tumors increased GPER protein expression, and survival of these BC patients was markedly reduced (95).

Currently, a hot topic in the field of $\mathrm{BC}$ research is the definition of the role of androgens and the androgen receptor (AR), with studies revealing both tumor promotion and inhibition (96-98). Expression of AR is associated with favorable prognosis depending on the BC subtype and on whether ER is expressed or not $(99,100)$. Recently, dihydroxytestosterone (DHT) bound to AR has been shown to directly mediate epigenetic modifications of the chromatin, regulating expression of target genes (101). AR binds to ARE on target genes and, with the help of Lysine-specific demethylase 1A (LSD1), regulates histone modifications, demethylation by LSD1 at H3K4 of the E-cadherin promoter represses gene expression; similarly, LSD1 demethylation at $\mathrm{H} 3 \mathrm{~K} 9$ activates vimentin gene expression. 
Importantly, LSD1 is crucial for epithelial to mesenchimal transition (EMT) induction in several cancer cells $(102,103)$.

Prostate cancer relays on distinct proliferative pathways, including the PI3K and RAS/RAF pathways downstream of membrane AR activation; dysregulation of these pathways in both early and late stage prostate cancer was demonstrated through genomic profiling (104). In prostate cancer, androgens, testosterone (T), and DHT stimulate proliferation and inhibit apoptosis. Androgen ablation using anti-androgens such as bicalutamide favors cancer regression. This event is related to a lower rate of cell proliferation and to an increased rate of cell death (105). However, many patients do not respond to this therapy and die of recurrent androgen-independent prostate cancer (AIPC), characterized by a high metastatic rate. A crosstalk between androgen-sensitive PCa cells, androgenindependent PCa cells, and PCa-derived stromal cells has been very recently highlighted (106). Adrenal dehydroepiandrosterone (DHEA) is metabolized to DHT in androgen-independent PCa cells (AR negative cells, AR-) as well as in stromal cells. DHT is able to activate $\mathrm{AR}$ in androgen sensitive $\mathrm{PCa}$ cells ( $\mathrm{AR}$ positive cells, $\mathrm{AR}+$ ). Crosstalk among these cells may increase the migration and invasion potential of androgen independent PCa cells via EMT, evidenced by induction of N-cadherin, Snail and vimentin (106). GPER seems to have a role in tumor growth and progression of triple negative breast cancers (TNBC), tumors that lack expression for $\mathrm{ER} \alpha$, progesterone receptor (PR) and HER2 $(107,108)$. AR directly binds to GPER promoter and treatment with DHT decreases its transcription, possibly by competitively blocking the binding of positive regulators of GPER transcription (109). This reduced GPER expression following DHT treatment, is associated with increased tumor growth (110). Indeed, GPER role in TNBC is still controversial, with some studies indicating GPER involvement in increased tumor growth and worse overall survival (OS) (108) and some others a positive correlation between GPER and OS (111).

Estrogens exert carcinogenic effects on the prostatic epithelium. Combination of estradiol with low-doses of testosterone increased the incidence of prostate carcinomas in a rat model of PCa (112). Similar effects were observed in a mouse model of PCa. When ER $\alpha$ was knocked out in those mice, chronic treatment with testosterone combined with estradiol was unable to induce PCa. Additionally, mice had reduced PCa incidence when aromatase was knocked out. All together these data indicate that autocrine-produced estradiol working through $\mathrm{ER} \alpha$ is determinant in PCa development (113). In agreement with animal studies, in the human prostatic epithelium $\mathrm{ER} \alpha$ is overexpressed during the malignant transformation, supporting its role as an oncogene (114). On the contrary, ER $\beta$ is considered a tumor suppressor; in fact, its expression is decreased or lost in about $40 \%$ of PCa (115).

Inhibitory functions of GPER activation in prostate cancers has been demonstrated both in vitro and in vivo (116).

\section{Statins and Steroid Production}

Statins, by decreasing cholesterol synthesis, will also affect the production of steroid hormones. Most steroid hormones are produced by the gonads and adrenal cortex from cholesterol, which is uptaken from the circulating LDL and HDL (117, 118). Since steroidogenesis requires an efficient intracellular pool of cholesterol, by reducing its synthesis, statin therapy could affect steroid production. Cortisol is a steroid hormone produced by the adrenal gland, is mainly released at times of stress, but in normal conditions, its production has a circadian rhythm (119). The effects of statin treatment on cortisol synthesis or cortisol levels were evaluated in several studies, that, however, did not demonstrate any significant effect of statins on cortisol levels $(120,121)$. An increase in plasma cortisol concentrations was highlighted by a recent meta-analysis study of data from seven randomized controlled trials with various statins (122). In general, the study demonstrated a higher impact of lipophilic statins (atorvastatin, lovastatin, and simvastatin), when compared to hydrophilic statins (pravastatin and rosuvastatin) (123). The increase in cortisol after statin treatment might explain the previously demonstrated anti-inflammatory effects of these drugs. The precise mechanism underling the rise in cortisol after statin use is not known. Studies evaluating the effect on hypothalamic-pituitary system or adrenal cortex itself should be performed to explain the mechanism activated by statins and responsible for the increase in cortisol levels. Based on the observation that only liphophilic statins, which have a greater non-hepatic distribution, affect cortisol levels, it can be speculated that statins have a direct effect on the adrenal gland. Enhancement of LDL-receptor expression, following the inhibition of adrenal HMG-CoA reductase, is responsible for increased cholesterol uptake allowing higher substrate availability for cortisol production. The effect of statins on the expression of steroidogenic enzymes involved in cortisol production is unknown.

A systematic review and meta-analysis of randomized controlled trials demonstrated that among 501 hypercholesterolemic men statins lowered testosterone; similarly, testosterone was reduced in a trial of 368 young women with polycystic ovary syndrome (PCOS) (124).

The direct effect of statins on HMG-CoA reductase in tumor cells is responsible for decreased substrate availability, lowering estrogens and androgens production that drive $\mathrm{BC}$ and PCa respectively. Recently, it has been found that statins and dehydroepiandrosterone sulfate (DHEAS) compete for the same transporter, SLCO2B1. Statin administration competitively reduces uptake of DHEAS and consequently tumor cell proliferation of PCa cell lines. The authors demonstrated that statin use at the time of androgen deprivation therapy initiation was associated with delayed tumor progression (125).

In physiological conditions, the prostate is not a steroidogenic site; but steroids, particularly testis-derived testosterone and DHT, regulate its function. In the context of a tumor, prostatic cells become capable of autonomous steroidogenesis (126). Evaluation of statin effects on the expression of steroidogenic enzymes in PC3 cells, demonstrated no effects on steroidogenic acute regulatory protein (StAR), cytochrome P450 family 11 subfamily A member 1 (CYP11A1), cytochrome P450 family 17 subfamily A member 1 (CYP17A1), hydroxy-delta-5-steroid dehydrogenase, 3 beta- and steroid delta-isomerase 2 (HSD3B2), 
steroid 5 alpha-reductase 2 (SRD5A2), and aldo-keto reductase family 1 member C2 (AKR1C2). Conversely, the expression of $17 \beta$-hydroxysteroid dehydrogenase type 5 (AKR1C3) was increased and $3 \beta$-hydroxysteroid dehydrogenase 1 (HSD3B1) was decreased. These changes in gene expression are responsible for the increase in DHT and T observed following simvastatin treatment (55).

All these studies suggest that steroidogenic tissues are potential sites for statins effect. On the adrenal gland there is no clear modulation of cortisol production, with only lipophilic statins having a direct effect on the adrenal and increasing cortisol synthesis. On the testis and PCOS statins reduce T production. In the context of tumors, there are discording data, reporting both decrease and increase in $\mathrm{T}$ production.

\section{Oxysterols Dependent-Cancer Growth and Progression}

Epidemiological studies evidenced that high levels of dietary cholesterol would increase the risk of $\mathrm{BC}$ in postmenopausal women and the risk of cancers of the stomach, colon, rectum, pancreas, lung, kidney, bladder and non-Hodgkin lymphoma (127). This is probably due to increased oxysterol production which parallels hypercholesterolemia. Elevated concentrations of oxysterols have been associated with colon (128), lung (129), breast $(130,131)$, skin (132), prostate (133), and bile duct (134) cancers.

Among oxysterols, 27HC is synthesized by CYP27A1, which has a broad substrate specificity and is present in most tissues and not only in the liver. However, 27HC is not an efficient activator of human LXRs (75), instead has been identified to bind ERs (135). 27HC, binds the ER $\alpha$ on epithelial cells of the mammary gland and promotes BC growth $(130,131)$, while binding $\mathrm{LXR} \alpha$ increases metastasis in the MMTV-PyMT mouse model of BC. Similarly, 25HC enhances cell proliferation of a breast cancer cell line via the activation of ER $\alpha$ target genes (136). Both 25HC and 27HC increased the transcription of ER target genes in longterm estrogen deprived BC cell lines, suggesting that these oxysterols replace estrogens and activate ER-mediated gene expression. This event can explain a mechanism involved in the development of resistance to aromatase inhibitors (137). Interestingly, BC patients treated with aromatase inhibitors had significantly increased plasma levels of $27 \mathrm{HC}$ and moderately increased levels of $25 \mathrm{HC}$ after 28 days of treatment (138), supporting a potential role of $25 \mathrm{HC}$ and $27 \mathrm{HC}$ level in patient outcome.

More recently, effects of $27 \mathrm{HC}$ have been studied in both androgen-responsive $\mathrm{LNCaP}(\mathrm{AR}+)$ cells and androgenirresponsive PC3 (AR-) prostate cancer cells. Both cell types increased proliferation in response to the oxysterol binding to $\operatorname{ER} \beta(133)$.

Oxysterol-binding protein (OSBP) (139) and OSBP-related proteins (ORPs) were originally isolated because of their ability to bind oxysterols, and later cholesterol (140). They comprise a 12-member mammalian gene family, characterized by a conserved OSBP homology domain (OHD) that binds sterols and lipids, as well as the pleckstrin homology $(\mathrm{PH})$ domain and two phenylalanines in an acidic tract (FFAT) motif that mediate interaction with organelle membranes. Upon binding to cholesterol, OSBP promotes ERK (extracellular signal regulated kinase) activity and hence cellular proliferation (140). Among them ORP4, also known as OSBP2, is expressed constitutively in brain, heart and testis, where is expressed as three variants, ORP4L, ORP4M, and ORP4S. Recently, cell growth regulatory activity has been evidenced for ORP4 (141). ORP4 binds sterols and phosphatidylinositol 4-phosphate (PI4P), and binding activity is required for ORP4 to promote cell proliferation and survival (141). Silencing of all ORP4 variants (ORP4L, ORP4M, ORP4S) in HEK293 and HeLa cells inhibited cell proliferation and promoted growth arrest without inducing cell death (141). ORP4L promoted proliferation of three different cervical carcinoma cell lines. (142). ORP4 has been identified as high-affinity cellular receptor for a group of natural products named ORPphilins that potently inhibit the growth of human cancer cell lines (143). Administration of 25HC, a high-affinity ligand for ORP4, suppressed ORPphilin activity.

\section{Statins and Oxysterols Production}

A recent phase II clinical trial aimed to investigate effects of statins on BC growth related to a reduction in $27 \mathrm{HC}$ levels. Patients were treated with $80 \mathrm{mg} /$ day of atorvastatin to investigate the impact of statin treatment on serum $27 \mathrm{HC}$ and on tumor-specific CYP27A1 expression. Atorvastatin exhibited an anti-proliferative effect evidenced by changes in Ki67 index, which did not significantly correlate with changes in either serum $27 \mathrm{HC}$ or changes in intratumoral CYP27A1 protein expression. Collectively these data indicate that the anti-proliferative responses to statin treatment do not depend on $27 \mathrm{HC}$ reduction (144).

However, 27HC can still affect proliferation of BC resistant to aromatase inhibitors (AI). It has been suggested that AIresistant tumors can still proliferate in response to $27 \mathrm{HC}$, which similarly to E2 activates ERs (131). In fact, despite lower estrogen levels, aromatase inhibitors resistant tumors have extensive $\mathrm{ER} \alpha$ binding to target genes. This is due to $\mathrm{ER} \alpha$ activation by $27 \mathrm{HC}$ synthesized consequently to stable up-regulation of the entire cholesterol biosynthetic pathways, including genes involved in $27 \mathrm{HC}$ biosynthesis. Statins, reducing cholesterol, reduce $27 \mathrm{HC}$, and decrease $\mathrm{ER} \alpha$ binding to DNA, abrogating cell invasion (145).

Statin treatments do not seem to have any beneficial effect on the rate of appearance of prostate cancer, but definitively has an effect on the incidence of advanced PCa (146-148). Moreover, in the PC3 prostate cancer cell line, statins prevent the cell migration potential therefore reducing the formation of metastatic prostate colonies; however, the mechanism relies on inhibition of prenylated proteins, not on inhibition of oxysterol formation (149).

These observations suggest that the reduction of oxysterol production by statins treatment could have effect on specific tumors preventing cell migration and invasion. 


\section{CHOLESTEROL AS SUBSTRATE FOR VITAMIN D SYNTHESIS}

Cholesterol is the precursor molecule for vitamin D. There are two major isoforms of vitamin $\mathrm{D}$ : vitamin $\mathrm{D}_{2}$ (ergocalciferol), and vitamin $\mathrm{D}_{3}$ (cholecalciferol) $(150,151)$. UVB radiations are needed to synthesize Vitamin $\mathrm{D}_{2}$ from ergosterol in plants, yeasts, and fungi and can be ingested from a diet containing food products of plant origin. In humans, vitamin $\mathrm{D}_{3}$ is synthesized from 7-dehydrocholesterol by UVB radiation in the epidermis of skin and can also be derived from the diet containing food products of animal origin.

Vitamin $\mathrm{D}$ is a prohormone that undergoes two-step metabolism in the liver by CYP27A1 to produce the $25(\mathrm{OH}) \mathrm{D}$ (calcidiol) and in the kidney by CYP27B1 to produce the biologically active metabolite $1 \alpha, 25(\mathrm{OH}) 2 \mathrm{D} 3$ (calcitriol) which binds to the vitamin $\mathrm{D}$ receptor (VDR) regulating expression of diverse genes (152). CYP27B1 is also expressed in multiple extra-renal sites, including cancer cells (153). Thus, calcitriol can function in an endocrine (systemic) or autocrine manner when it is locally synthesized. Serum level of 30 to $50 \mathrm{ng} / \mathrm{mL}$ is normal for healthy people. Vitamin D deficiency and insufficiency is defined as serum 25-hydroxyvitamin D [25(OH)D] levels $<20$ and 21 to $29 \mathrm{ng} / \mathrm{mL}$, respectively.

Recent studies have revealed that vitamin $\mathrm{D}$ can also be metabolized and activated through a CYP11A1-driven noncanonical metabolic pathway (154). The products of CYP11A1, such as $20(\mathrm{OH}) \mathrm{D}$ and its hydroxy-metabolites, produce differentiation, have anti-proliferative and anti-inflammatory effects in skin cells comparable or superior to calcitriol (155). Low vitamin D levels increase cancer risk, as evidenced by epidemiological, preclinical and cellular studies (154, 156). In particular, many in vitro studies, performed in several malignant cell lines, showed that the anti-cancer activity of this molecule is related to the inhibition of proliferation and angiogenesis and induction of apoptosis (157).

Epidemiological studies showed that serum levels of $25(\mathrm{OH}) \mathrm{D}$ adversely correlate with prostate cancer risk (158). In men living at high latitude, as in Scandinavia, 25(OH)D blood serum levels are below $16 \mathrm{ng} / \mathrm{mL}$ and the incidence of prostate cancer is high (159). It was observed that $1 \alpha, 25(\mathrm{OH}) 2 \mathrm{D} 3$ inhibited proliferation and stimulated apoptosis of VDR-positive prostate cancer cells and, interestingly had an anti-inflammatory effect toward this subtype of prostate tumors (160).

In $\mathrm{BC}$ cells $1 \alpha, 25(\mathrm{OH}) 2 \mathrm{D} 3$ caused cell cycle arrest, by interfering with cyclin-dependent kinases activity (161). Additionally, apoptosis can be activated by reducing bcl-2 and up-regulating p53 levels (162). Cell proliferation can be inhibited by $1 \alpha, 25(\mathrm{OH}) 2 \mathrm{D} 3$, interfering with ER function. Specifically, $1 \alpha, 25(\mathrm{OH}) 2 \mathrm{D} 3$ and its analogs down-regulate the expression of $\mathrm{ER} \alpha$, which in turn reduced estrogen-dependent activation of mitogenic signal (163). Another action of $1 \alpha, 25(\mathrm{OH}) 2 \mathrm{D} 3$ against breast cancer cells is the down-regulation of aromatase expression (164).

Proliferation of colon cancer cells was inhibited by $1 \alpha, 25(\mathrm{OH}) 2 \mathrm{D} 3$ and its analogs, that caused a cell cycle arrest at the G0/G1 phase. This was consequent to enhanced expression of p21 and p27, two cyclin-dependent kinase inhibitors, and to reduced expression of cyclin D1 and cyclin E (165). In addition, following colon cancer cells treatment with $1 \alpha, 25(\mathrm{OH}) 2 \mathrm{D} 3$, genes with a pro-apoptotic function were increased, while those anti-apoptotic were downregulated (166). It was observed that

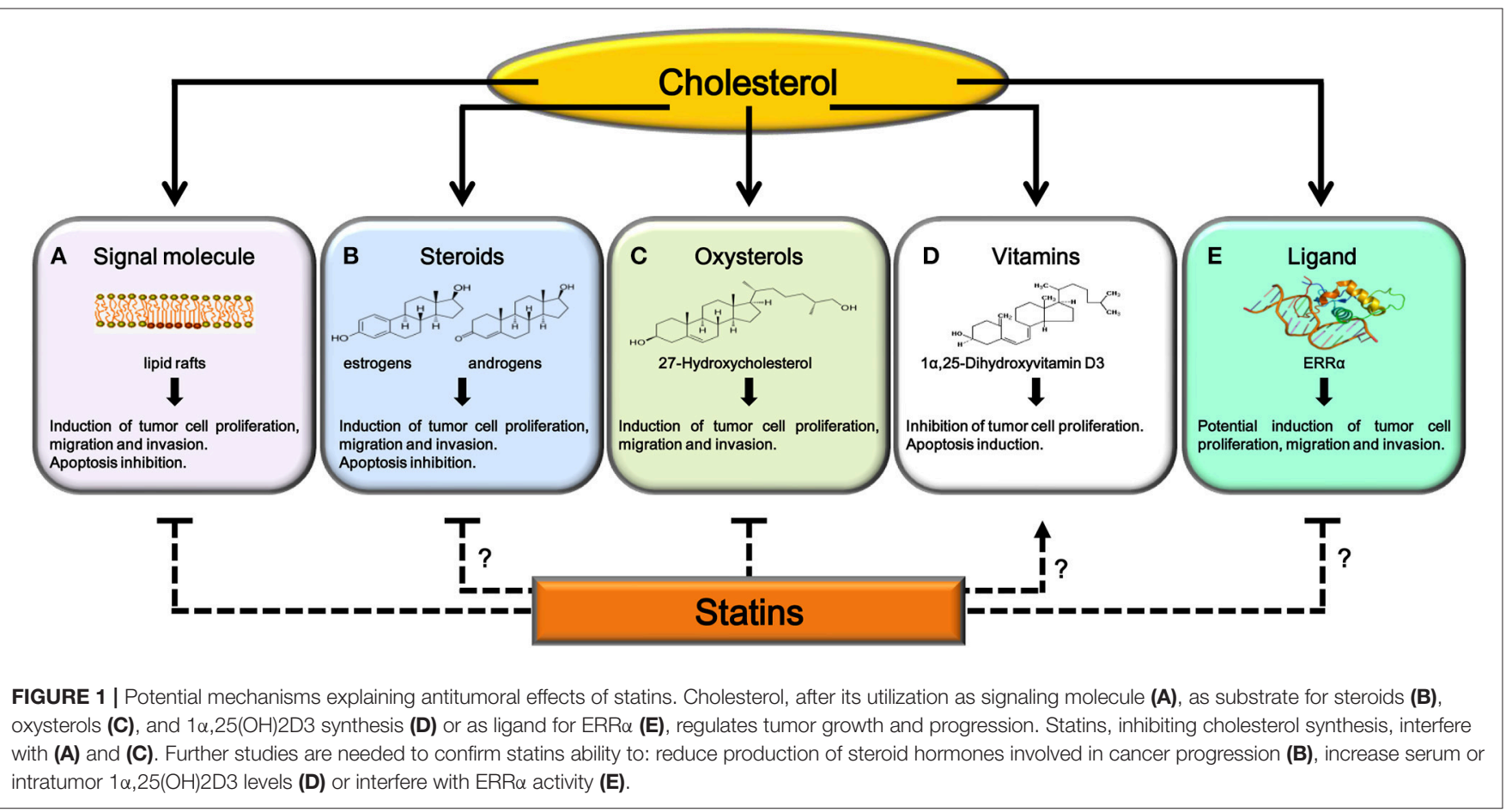


in differentiated human colon tumors CYP27B1 expression is enhanced compared to untransformed colon mucosa. It was observed a parallel increase of VDR and CYP27B1 mRNA during early tumor progression. This suggests that $1 \alpha, 25(\mathrm{OH}) 2 \mathrm{D} 3$ synthesized in colonocytes and bound to its receptor could exert its anti-mitotic function in both an autocrine and a paracrine fashion to prevent intestinal tumor formation and progression during early phases of colon tumorigenesis. In fact, in high-grade undifferentiated tumors, expression of CYP27B1 is decreased (167). However, other reports did not find a rise in CYP27B1 expression in tumors, possibly because there was not a distinction for the biological grade of the tumor (168). With a very similar pattern of expression, when compared with normal colon mucosa, VDR expression is increased in early stages of tumorigenesis, but declines in late-stage tumors (169-171). Alternatively, $1 \alpha, 25(\mathrm{OH}) 2 \mathrm{D} 3$ produced during early phases of transformation could interact with other receptors such as thyroid receptors (TR) (172) and induce cell proliferation. In fact, the expression of TR $\beta 1$ was found associated with polypoid growth and with higher histological grade and advanced stage (173). To confirm a protective role for $1 \alpha, 25(\mathrm{OH}) 2 \mathrm{D} 3, \mathrm{CYP} 24 \mathrm{~A} 1$, the degrading enzyme, has enhanced expression in the majority of colon adenocarcinomas, keeping low $1 \alpha, 25(\mathrm{OH}) 2 \mathrm{D} 3$ levels (174). Adrenocortical cancers express VDR, its activation by slightly supra-physiological concentrations of $1 \alpha, 25(\mathrm{OH}) 2 \mathrm{D} 3$ has a moderate anti-proliferative effect, that is related to cell cycle arrest, promoting accumulation of cells in G1 phase, without inducing apoptosis. Additionally, VDR activation decreases cortisol, aldosterone, and DHEA-S production (175).

A very recent study demonstrated no impact of statin therapy on plasma vitamin D levels (176). However, a meta-analysis report indicated opposite data, with statins causing an increase in vitamin D serum levels (177), this effect was observed with lovastatin (178), simvastatin (179), atorvastatin (180), and especially rosuvastatin $(181,182)$. If further confirmed, these data might help explaining the anti-neoplastic effect exerted by statins on colon cancer (183-185). Currently, there are no studies investigating the effects of statins on intratumor vitamin D synthesis despite vitamin D can act in an autocrine manner to regulate cancer growth. For these reasons further studies on specific tumor are necessary to establish a direct effect of vitamin $\mathrm{D}$ on cell tumor proliferation and consequently if statins could induce anti-tumoral effects modulating intra-tumoral vitamin D levels.

\section{CHOLESTEROL AS ESTROGEN-RELATED RECEPTOR ALPHA (ERR $\alpha$ ) LIGAND}

The Estrogen-related receptor (ERR) family is known to comprise three members [ERR $\alpha$ (NR3B1), ERR $\beta$ (NR3B2), and $\mathrm{ERR} \gamma$ (NR3B3)] (186). ERR $\alpha$ is ubiquitously expressed in adult tissues; ERR $\beta$ is detected at low levels in the liver, skeletal muscle, stomach, heart, and kidney; ERR $\gamma$ is widely expressed and can be detected in brain, lung, bon marrow, adrenal and thyroid glands, trachea and spinal cord. The ERRs, like most NRs, are organized in functional domains for ligand (LBD) and DNA binding (DBD), in addition to an activation function 1 (AF-1) involved in cofactors binding. $\mathrm{ER} \alpha$ and $\mathrm{ERR} \alpha \mathrm{LBD}$ share only $37 \%$ amino acid homology, indicating low affinity for common ligands, and in fact estradiol fails in activating $\operatorname{ERR} \alpha$ (186). While $\operatorname{ERR} \beta$ and $\operatorname{ERR} \gamma$ are still orphan receptors since their natural ligands have not been identified, ERR $\alpha$ is an adopted orphan receptor, for which ligand has been identified to be cholesterol (187). This finding implies cholesterol involvement in mitochondrial metabolism and biogenesis. In fact, ERR $\alpha$ regulates the expression of a broad range of genes driving mitochondrial biogenesis, the tricarboxylic acid (TCA) cycle, and substrate oxidation.

ERR monomers preferentially recognize the consensus site referred to as the ERR-response element (ERRE). ERR $\alpha$ and $\mathrm{ER} \alpha$ share $68 \%$ amino acid identity in the $\mathrm{DBD}$, indicating that the two receptors can potentially regulate common genes. Indeed ERR dimers can bind to the ERE, and ER $\alpha$ dimers can also recognize ERRE sites (188). ER $\alpha$ and the ERRs compete for common coactivators such as steroid receptor coactivator (SRC) proteins in transfected cells (189). In addition, another coactivator, the small heterodimer partner (SHP), a coregulator of ER, interacts with all members of the ERR family inhibiting their transcriptional activity. Thus, ERRs and ERs have the potential to differentially regulate common target genes.

$E R R \alpha$ transcriptional activity in normal cells has important roles in cellular metabolism, this is particularly relevant in rapidly dividing cells such as tumor cells. Cholesterol interaction with ERR $\alpha$ (187) allows recruitment of coactivators PGC $1 \alpha / \beta$ and increases ERR $\alpha$ transcriptional activity. ERR $\alpha$ interaction with PGC1 $\alpha$ favors osteoclastogenesis (190) and bone reabsorption in osteoclasts, myogenesis (191) and decreases muscle toxicity in myocytes (187). Differently from other nuclear receptors, ERR $\alpha$ is constitutively active because cholesterol is ubiquitous, meaning that it does not require any spike in ligand concentration, as is the case for steroid hormone receptors. $\operatorname{ERR} \alpha$ antagonists have been found to induce cancer cell death $(192,193)$, inhibit tumor growth (194) and improve insulin sensitivity and glucose tolerance (195).

The use of statins or drugs targeting the SREBP metabolic pathways could be a promising option to counteract ERR $\alpha$ dependent metabolic rearrangement. Identification of cholesterol as $E R R \alpha$ ligand is relatively new, so far no studies have investigated statins effects on $\mathrm{ERR} \alpha$ activity in tumor cells. However, the discovery of cholesterol as ERR $\alpha$ ligand has elucidated the mechanism behind statin-induced muscle toxicity (187).

\section{CONCLUSIONS}

Statins are widely used drugs for their ability to lower cholesterol levels in hypercholesterolemic patients. Their mechanism of action consists in the inhibition of HMG-CoA reductase, the main enzyme involved in cholesterol biosynthesis. 
Aim of this review was to discuss the results of studies focused on the use of statins to the purpose of interfering with cholesterol activities, in order to prevent cancer growth and metastasis.

Cholesterol plays an important function as part of membrane rafts where is involved in the modulation of signaling transduction related to cell proliferation and migration (Figure 1A). Data discussed herein unequivocally suggest that statins have a direct impact on the function of membrane rafts, inhibiting, in tumor cells, pathways regulating growth, and metastasis. Cholesterol represents a precursor for estrogens and androgens, hormones involved in modulating cell proliferation, migration, invasion and apoptosis in different cancers (Figure 1B). Even though steroidogenic tissues are potential sites for statins effects, there are discording data on a direct role for statins in decreasing steroid production in hormone-dependent cancers. Furthermore, using cholesterol as substrate for specific metabolizing enzymes it is also possible to produce oxysterols, such as $27 \mathrm{HC}$, which has been shown to act as an endogenous selective estrogen receptor modulator able to increase cancer growth and metastasis (Figure 1C). Data discussed in this review suggest that the reduction of oxysterol production caused by statins could have a strong effect on specific tumors (i.e., breast cancer) preventing cell migration and invasion.

Cholesterol is also precursor of vitamin $1 \alpha, 25(\mathrm{OH}) 2 \mathrm{D} 3$, which is involved in modulating VDR-responsive genes, encoding for proteins involved in anti-proliferative signaling (Figure 1D). However, the analysis of data published in this field suggest that further studies are necessary to establish a direct effect (anti-proliferative or proliferative) of vitamin D on different cell tumors and consequently if statins could induce specific effects modulating intra-tumoral vitamin D levels.

In conclusion, while the anti-tumor effects produced by statins on cholesterol-mediated transduction mechanisms at the membrane raft or on oxysterols synthesis, appear to be a

\section{REFERENCES}

1. Simons K, Ikonen E. How cells handle cholesterol. Science (2000) 290:1721-6. doi: 10.1126/science.290.5497.1721

2. Slater HR, McKinney L, Packard CJ, Shepherd J. Contribution of the receptor pathway to low density lipoprotein catabolism in humans. New methods for quantitation. Arteriosclerosis (1984) 4:604-13. doi: 10.1161/01.ATV.4.6.604

3. Brown MS, Goldstein JL. Cholesterol feedback: from Schoenheimer's bottle to Scap's MELADL. J Lipid Res. (2009) 50(Suppl):S15-27. doi: 10.1194/jlr.R800054-JLR200

4. Casey PJ. Mechanisms of protein prenylation and role in $\mathrm{G}$ protein function. Biochem Soc Trans. (1995) 23:161-6. doi: 10.1042/bst0230161

5. Kuzu OF, Noory MA, Robertson GP. The role of cholesterol in cancer. Cancer Res. (2016) 76:2063-70. doi: 10.1158/0008-5472.CAN-15-2613

6. Lee SS, Ho KJ. Cholesterol fatty kidney: morphological changes in the course of its development in rabbits. Exp Mol Pathol. (1978) 29:412-25. doi: 10.1016/0014-4800(78)90082-5

7. Azrolan NI, Coleman PS. A discoordinate increase in the cellular amount of 3-hydroxy-3-methylglutaryl-CoA reductase results in the loss of ratelimiting control over cholesterogenesis in a tumour cell-free system. Biochem J. (1989) 258:421-5. doi: 10.1042/bj2580421

8. Gould RG. Lipid metabolism and atherosclerosis. Am J Med. (1951) 11:209-27. doi: 10.1016/0002-9343(51)90107-6 promising therapeutic strategy, further studies are needed to determine if cholesterol depletion is a valid strategy to limit the effects of steroid hormones on endocrine-dependent tumors. The ability of statins to increase $1 \alpha, 25(\mathrm{OH}) 2 \mathrm{D} 3$ serum levels need to be confirmed, in order to define another antitumor mechanism for these drugs. Recently, the discovery of cholesterol as ERR $\alpha$ ligand has elucidated the mechanism behind statininduced muscle toxicity; however, no studies have investigated statins effects on ERR $\alpha$ activity in tumor cells (Figure 1E). This last aspect has opened a new field of investigation, in fact, strategies aimed to reduce cholesterol levels, such as the use of statins or drugs targeting SREBP metabolic pathways, could be a promising option to counteract metabolic rewiring in cancer cells where ERR $\alpha$ plays a pivotal role.

Preclinical studies support the potential use of statins as anticancer agents. Epidemiological studies indicate that statin use is associated with a reduction in the incidence of some tumor types. The few clinical trials of statins as monotherapy do not provide convincing results; however, in combination therapy with other agents, statins have shown more promising data. Conclusion of clinical trials not yet completed and publication of data from closed trials will provide a wider picture on the effectiveness of this class of drugs as anticancer therapy.

\section{AUTHOR CONTRIBUTIONS}

AC, IC: literature search and drafting of the article. FT, PA, AD, VR: drafting of the article. VP, RS: critical revision of the article and final approval.

\section{FUNDING}

This work was supported by AIRC (Associazione Italiana per la Ricerca sul Cancro), projects n. IG15230 and IG20122.

9. Tomkins GM, Sheppard H, Chaikoff IL. Cholesterol synthesis by liver. IV. Suppression by steroid administration. J Biological Chem. (1953) 203:781-6.

10. Siperstein MD, Guest MJ. Studies on the site of the feedback control of cholesterol synthesis. J Clin Investig. (1960) 39:642-52. doi: 10.1172/JCI104079

11. Siperstein MD, Fagan VM. Feedback control of mevalonate synthesis by dietary cholesterol. J Biol Chem. (1966) 241:602-9.

12. Linn TC. The effect of cholesterol feeding and fasting upon beta-hydroxy-beta-methylglutaryl coenzyme A reductase. J Biol Chem. (1967) 242:990-3.

13. Swann A, Wiley MH, Siperstein MD. Tissue distribution of cholesterol feedback control in the guinea pig. J Lipid Res. (1975) 16:360-6.

14. Wong WW, Dimitroulakos J, Minden MD, Penn LZ. HMG-CoA reductase inhibitors and the malignant cell: the statin family of drugs as triggers of tumor-specific apoptosis. Leukemia (2002) 16:508-19. doi: 10.1038/sj.leu.2402476

15. Zhong S, Zhang X, Chen L, Ma T, Tang J, Zhao J. Statin use and mortality in cancer patients: systematic review and meta-analysis of observational studies. Cancer Treatment Rev. (2015) 41:554-67. doi: 10.1016/j.ctrv.2015.04.005

16. Yu O, Eberg M, Benayoun S, Aprikian A, Batist G, Suissa S, et al. Use of statins and the risk of death in patients with prostate cancer. J Clin Oncol. (2014) 32:5-11. doi: 10.1200/JCO.2013.49.4757 
17. Krens LL, Simkens LH, Baas JM, Koomen ER, Gelderblom H, Punt CJ, et al. Statin use is not associated with improved progression free survival in cetuximab treated KRAS mutant metastatic colorectal cancer patients: results from the CAIRO2 study. PLOS ONE (2014) 9:e112201. doi: 10.1371/journal.pone.0112201

18. Shao YY, Hsu CH, Yeh KH, Chen HM, Yeh YC, Lai CL, et al. Statin use is associated with improved prognosis of colorectal cancer in Taiwan. Clin Colorectal Cancer (2015) 14:177-184.e4. doi: 10.1016/j.clcc.2015. 02.003

19. Viers BR, Houston Thompson R, Psutka SP, Lohse CM, Cheville JC, Leibovich BC, et al. The association of statin therapy with clinicopathologic outcomes and survival among patients with localized renal cell carcinoma undergoing nephrectomy. Urologic Oncol. (2015) 33:388e11-8. doi: 10.1016/j.urolonc.2015.01.009

20. Cardwell CR, Hicks BM, Hughes C, Murray LJ. Statin use after diagnosis of breast cancer and survival: a population-based cohort study. Epidemiology (2015) 26:68-78. doi: 10.1097/EDE.0000000000000189

21. Habis M, Wroblewski K, Bradaric M, Ismail N, Yamada SD, Litchfield L, et al. Statin therapy is associated with improved survival in patients with nonserous-papillary epithelial ovarian cancer: a retrospective cohort analysis. PLoS ONE (2014) 9:e104521. doi: 10.1371/journal.pone.0104521

22. Nowakowski GS, Maurer MJ, Habermann TM, Ansell SM, Macon WR, Ristow KM, et al. Statin use and prognosis in patients with diffuse large Bcell lymphoma and follicular lymphoma in the rituximab era. J Clin Oncol. (2010) 28:412-7. doi: 10.1200/JCO.2009.23.4245

23. Vuorio A, Kuoppala J, Kovanen PT, Humphries SE, Tonstad S, Wiegman A, et al. Statins for children with familial hypercholesterolemia. Cochr Database Syst Rev. (2017) 7:CD006401. doi: 10.1002/14651858.CD006401.pub4

24. Clendening JW, Penn LZ. Targeting tumor cell metabolism with statins. Oncogene (2012) 31:4967-78. doi: 10.1038/onc.2012.6

25. Livingstone E, Hollestein LM, van Herk-Sukel MP, van de Poll-Franse L, Joosse A, Schilling B, et al. Statin use and its effect on all-cause mortality of melanoma patients: a population-based Dutch cohort study. Cancer Med. (2014) 3:1284-93. doi: 10.1002/cam4.285

26. Nam DH, Lee H, Park JC, Shin SK, Lee SK, Hyung WJ, et al. Long-term statin therapy improves oncological outcome after radical gastrectomy for stage II and III gastric cancer. Anticancer Res. (2014) 34:355-61.

27. Wang Z, Li Y, Banerjee S, Kong D, Ahmad A, Nogueira V, et al. Down-regulation of Notch-1 and Jagged-1 inhibits prostate cancer cell growth, migration and invasion, and induces apoptosis via inactivation of Akt, mTOR, and NF-kappaB signaling pathways. J Cell Biochem. (2010) 109:726-36. doi: 10.1002/jcb.22451

28. Sezgin E, Levental I, Mayor S, Eggeling C. The mystery of membrane organization: composition, regulation and roles of lipid rafts. Nat Rev Mol Cell Biol. (2017) 18:361-74. doi: 10.1038/nrm.2017.16

29. Ikonen E. Roles of lipid rafts in membrane transport. Curr Opin Cell Biol. (2001) 13:470-7. doi: 10.1016/S0955-0674(00)00238-6

30. Lisanti MP, Scherer PE, Vidugiriene J, Tang Z, Hermanowski-Vosatka A, $\mathrm{Tu} \mathrm{YH}$, et al. Characterization of caveolin-rich membrane domains isolated from an endothelial-rich source: implications for human disease. J Cell Biol. (1994) 126:111-26. doi: 10.1083/jcb.126.1.111

31. Jeong J, McMahon AP. Cholesterol modification of Hedgehog family proteins. J Clin Investig. (2002) 110:591-6. doi: 10.1172/JCI02 16506

32. Gao X, Lowry PR, Zhou X, Depry C, Wei Z, Wong GW, et al. PI3K/Akt signaling requires spatial compartmentalization in plasma membrane microdomains. Proc Natl Acad Sci USA. (2011) 108:14509-14. doi: $10.1073 /$ pnas. 1019386108

33. Shukla S, Gupta S. Apigenin-induced cell cycle arrest is mediated by modulation of MAPK, PI3K-Akt, and loss of cyclin D1 associated retinoblastoma dephosphorylation in human prostate cancer cells. Cell Cycle (2007) 6:1102-14. doi: 10.4161/cc.6.9.4146

34. Courtney KD, Corcoran RB, Engelman JA. The PI3K pathway as drug target in human cancer. J Clin Oncol. (2010) 28:1075-83. doi: 10.1200/JCO.2009.25.3641

35. Chen X, Resh MD. Cholesterol depletion from the plasma membrane triggers ligand-independent activation of the epidermal growth factor receptor. J Biol Chem. (2002) 277:49631-7. doi: 10.1074/jbc.M208327200
36. Adam RM, Mukhopadhyay NK, Kim J, Di Vizio D, Cinar B, Boucher K, et al. Cholesterol sensitivity of endogenous and myristoylated Akt. Cancer Res. (2007) 67:6238-46. doi: 10.1158/0008-5472.CAN-07-0288

37. Elmore S. Apoptosis: a review of programmed cell death. Toxicol Pathol. (2007) 35:495-516. doi: 10.1080/01926230701320337

38. Oliferenko S, Paiha K, Harder T, Gerke V, Schwarzler C, Schwarz H, et al. Analysis of CD44-containing lipid rafts: Recruitment of annexin II and stabilization by the actin cytoskeleton. J Cell Biol. (1999) 146:843-54. doi: $10.1083 /$ jcb.146.4.843

39. Murai T. The role of lipid rafts in cancer cell adhesion and migration. Int $J$ Cell Biol. (2012) 2012:763283. doi: 10.1155/2012/763283

40. Murai T, Sato C, Sato M, Nishiyama H, Suga M, Mio K, et al. Membrane cholesterol modulates the hyaluronan-binding ability of CD44 in $\mathrm{T}$ lymphocytes and controls rolling under shear flow. J Cell Sci. (2013) 126:3284-94. doi: 10.1242/jcs.120014

41. Li YC, Park MJ, Ye SK, Kim CW, Kim YN. Elevated levels of cholesterol-rich lipid rafts in cancer cells are correlated with apoptosis sensitivity induced by cholesterol-depleting agents. Am J Pathol. (2006) 168:1107-18; quiz 1404-5. doi: 10.2353/ajpath.2006.050959

42. Coogan PF, Rosenberg L, Palmer JR, Strom BL, Zauber AG, Shapiro S. Statin use and the risk of breast and prostate cancer. Epidemiology (2002) 13:262-7. doi: 10.1097/00001648-200205000-00005

43. Galbiati F, Razani B, Lisanti MP. Emerging themes in lipid rafts and caveolae. Cell (2001) 106:403-11. doi: 10.1016/S0092-8674(01)00472-X

44. Gajate C, Gonzalez-Camacho F, Mollinedo F. Lipid raft connection between extrinsic and intrinsic apoptotic pathways. Biochem Biophys Res Commun. (2009) 380:780-4. doi: 10.1016/j.bbrc.2009.01.147

45. Li AJ, Elmore RG, Pavelka JC, Karlan BY. Hyperandrogenism, mediated by obesity and receptor polymorphisms, promotes aggressive epithelial ovarian cancer biology. Gynecol Oncol. (2007) 107:420-3. doi: 10.1016/j.ygyno.2007.07.059

46. Song JH, Tse MC, Bellail A, Phuphanich S, Khuri F, Kneteman NM, et al. Lipid rafts and nonrafts mediate tumor necrosis factor related apoptosis-inducing ligand induced apoptotic and nonapoptotic signals in non small cell lung carcinoma cells. Cancer Res. (2007) 67:6946-55. doi: 10.1158/0008-5472.CAN-06-3896

47. Badana AK, Chintala M, Gavara MM, Naik S, Kumari S, Kappala VR, et al. Lipid rafts disruption induces apoptosis by attenuating expression of LRP6 and survivin in triple negative breast cancer. Biomed Pharmacother. (2018) 97:359-68. doi: 10.1016/j.biopha.2017.10.045

48. Raghu H, Sodadasu PK, Malla RR, Gondi CS, Estes N, Rao JS. Localization of UPAR and MMP-9 in lipid rafts is critical for migration, invasion and angiogenesis in human breast cancer cells. BMC Cancer (2010) 10:647. doi: 10.1186/1471-2407-10-647

49. Staubach S, Hanisch FG. Lipid rafts: signaling and sorting platforms of cells and their roles in cancer. Expert Rev Proteomics (2011) 8:263-77. doi: 10.1586/epr.11.2

50. Waugh MG, Minogue S, Anderson JS, dos Santos M, Hsuan JJ. Signalling and non-caveolar rafts. Biochem Soc Transact. (2001) 29:509-11. doi: 10.1042/bst0290509

51. Menter DG, Ramsauer VP, Harirforoosh S, Chakraborty K, Yang P, Hsi $L$, et al. Differential effects of pravastatin and simvastatin on the growth of tumor cells from different organ sites. PLoS ONE (2011) 6:e28813. doi: 10.1371/journal.pone.0028813

52. Zhuang L, Kim J, Adam RM, Solomon KR, Freeman MR. Cholesterol targeting alters lipid raft composition and cell survival in prostate cancer cells and xenografts. J Clin Investig. (2005) 115:959-68. doi: 10.1172/JCI200519935

53. Dimitroulakos J, Lorimer IA, Goss G. Strategies to enhance epidermal growth factor inhibition: targeting the mevalonate pathway. Clin Cancer Res. (2006) 12:4426s-31s. doi: 10.1158/1078-0432.CCR-06-0089

54. Sekine Y, Furuya Y, Nishii M, Koike H, Matsui H, Suzuki K. Simvastatin inhibits the proliferation of human prostate cancer PC-3 cells via downregulation of the insulin-like growth factor 1 receptor. Biochem Biophys Res Commun. (2008) 372:356-61. doi: 10.1016/j.bbrc.2008.05.043

55. Sekine Y, Nakayama H, Miyazawa Y, Kato H, Furuya Y, Arai S, et al. Simvastatin in combination with meclofenamic acid inhibits the proliferation and migration of human prostate cancer PC-3 
cells via an AKR1C3 mechanism. Oncol Lett. (2018) 15:3167-72. doi: 10.3892/ol.2017.7721

56. Garnett DJ, Greenhough TJ. Statins cause profound effects on gene expression in human cancer cells in vitro: the role of membrane microdomains. Gene Expression (2012) 15:225-34. doi: $10.3727 / 105221613 X 13571653093240$

57. Walz C, Crowley BJ, Hudon HE, Gramlich JL, Neuberg DS, Podar K, et al. Activated Jak2 with the V617F point mutation promotes G1/S phase transition. J Biol Chem. (2006) 281:18177-83. doi: 10.1074/jbc.M600064200

58. Jedidi A, Marty C, Oligo C, Jeanson-Leh L, Ribeil JA, Casadevall $\mathrm{N}$, et al. Selective reduction of JAK2V617F-dependent cell growth by siRNA/shRNA and its reversal by cytokines. Blood (2009) 114:1842-51. doi: 10.1182/blood-2008-09-176875

59. Griner LN, McGraw KL, Johnson JO, List AF, Reuther GW. JAK2V617F-mediated signalling is dependent on lipid rafts and statins inhibit JAK2-V617F-dependent cell growth. Br J Haematol. (2013) 160:177-87. doi: 10.1111/bjh.12103

60. von Tresckow B, Kallen KJ, von Strandmann EP, Borchmann P, Lange H, Engert A, et al. Depletion of cellular cholesterol and lipid rafts increases shedding of CD30. J Immunol. (2004) 172:4324-31. doi: 10.4049/jimmunol.172.7.4324

61. Mechtersheimer S, Gutwein P, Agmon-Levin N, Stoeck A, Oleszewski M, Riedle $\mathrm{S}$, et al. Ectodomain shedding of $\mathrm{L} 1$ adhesion molecule promotes cell migration by autocrine binding to integrins. J Cell Biol. (2001) 155:661-73. doi: $10.1083 /$ jcb. 200101099

62. Zimina EP, Bruckner-Tuderman L, Franzke CW. Shedding of collagen XVII ectodomain depends on plasma membrane microenvironment. J Biol Chem. (2005) 280:34019-24. doi: 10.1074/jbc.M503751200

63. Veit G, Zimina EP, Franzke CW, Kutsch S, Siebolds U, Gordon MK, et al. Shedding of collagen XXIII is mediated by furin and depends on the plasma membrane microenvironment. J Biol Chem. (2007) 282:27424-35. doi: 10.1074/jbc.M703425200

64. Miller T, Yang F, Wise CE, Meng F, Priester S, Munshi MK, et al. Simvastatin stimulates apoptosis in cholangiocarcinoma by inhibition of Racl activity. Dig Liver Dis. (2011) 43:395-403. doi: 10.1016/j.dld.2011.01.010

65. Payne AH, Hales DB. Overview of steroidogenic enzymes in the pathway from cholesterol to active steroid hormones. Endocr Rev. (2004) 25:947-70. doi: 10.1210/er.2003-0030

66. Baulieu EE. Neurosteroids: a novel function of the brain. Psychoneuroendocrinology 23:963-87. doi: 10.1016/S0306-4530(98)00071-7

67. Mellon SH, Griffin LD. Neurosteroids: biochemistry and clinical significance. Trends Endocrinol Metab. (2002) TEM 13:35-43. doi: 10.1016/S1043-2760(01)00503-3

68. Kayes-Wandover KM, White PC. Steroidogenic enzyme gene expression in the human heart. J Clin Endocrinol Metab. (2000) 85:2519-25. doi: 10.1210/jc.85.7.2519

69. Labrie F, Belanger A, Luu-The V, Labrie C, Simard J, Cusan L, et al. DHEA and the intracrine formation of androgens and estrogens in peripheral target tissues: its role during aging. Steroids (1998) 63:322-8. doi: 10.1016/S0039-128X(98)00007-5

70. Russell DW. Oxysterol biosynthetic enzymes. Biochim Biophys Acta (2000) 1529:126-35. doi: 10.1016/S1388-1981(00)00142-6

71. Luoma PV. Cytochrome P450-physiological key factor against cholesterol accumulation and the atherosclerotic vascular process. Ann Med. (2007) 39:359-70. doi: 10.1080/07853890701379767

72. Bjorkhem I. Rediscovery of cerebrosterol. Lipids (2007) 42:5-14. doi: 10.1007/s11745-006-1003-2

73. Bjorkhem I, Eggertsen G. Genes involved in initial steps of bile acid synthesis. Curr Opin lipidol. (2001) 12:97-103. doi: 10.1097/00041433-200104000-00002

74. Babiker A, Andersson O, Lund E, Xiu RJ, Deeb S, Reshef A, et al. Elimination of cholesterol in macrophages and endothelial cells by the sterol 27-hydroxylase mechanism. Comparison with high density lipoproteinmediated reverse cholesterol transport. J Biol Chem. (1997) 272:26253-61. doi: $10.1074 / \mathrm{jbc} .272 .42 .26253$

75. Lehmann JM, Kliewer SA, Moore LB, Smith-Oliver TA, Oliver BB, Su $\mathrm{JL}$, et al. Activation of the nuclear receptor LXR by oxysterols defines a new hormone response pathway. J Biol Chem. (1997) 272:3137-40. doi: 10.1074/jbc.272.6.3137

76. Janowski BA, Willy PJ, Devi TR, Falck JR, Mangelsdorf DJ. An oxysterol signalling pathway mediated by the nuclear receptor LXR alpha. Nature (1996) 383:728-31. doi: 10.1038/383728a0

77. Cummins CL, Volle DH, Zhang Y, McDonald JG, Sion B, LefrancoisMartinez AM, et al. Liver $\mathrm{X}$ receptors regulate adrenal cholesterol balance. J Clin Investig. (2006) 116:1902-12. doi: 10.1172/JCI28400

78. Repa JJ, Mangelsdorf DJ. The role of orphan nuclear receptors in the regulation of cholesterol homeostasis. Ann Rev Cell Devel Biol. (2000) 16:459-81. doi: 10.1146/annurev.cellbio.16.1.459

79. Chawla A, Repa JJ, Evans RM, Mangelsdorf DJ. Nuclear receptors and lipid physiology: opening the X-files. Science (2001) 294:1866-70. doi: $10.1126 /$ science.294.5548.1866

80. Repa JJ, Turley SD, Lobaccaro JA, Medina J, Li L, Lustig K, et al. Regulation of absorption and ABC1-mediated efflux of cholesterol by RXR heterodimers. Science (2000) 289:1524-9. doi: 10.1126/science.289.5484.1524

81. Venkateswaran A, Repa JJ, Lobaccaro JM, Bronson A, Mangelsdorf DJ, Edwards PA. Human white/murine ABC8 mRNA levels are highly induced in lipid-loaded macrophages. A transcriptional role for specific oxysterols. J Biol Chem. (2000) 275:14700-7. doi: 10.1074/jbc.275.19.14700

82. Venkateswaran A, Laffitte BA, Joseph SB, Mak PA, Wilpitz DC, Edwards $\mathrm{PA}$, et al. Control of cellular cholesterol efflux by the nuclear oxysterol receptor LXR alpha. Proc Natl Acad Sci US A. (2000) 97:12097-102. doi: $10.1073 /$ pnas. 200367697

83. Luo Y, Tall AR. Sterol upregulation of human CETP expression in vitro and in transgenic mice by an LXR element. J Clin Investig. (2000) 105:513-20. doi: 10.1172/JCI8573

84. Hamilton KJ, Hewitt SC, Arao Y, Korach KS. Estrogen hormone biology. Curr Topics Devel Biol. (2017) 125:109-46. doi: 10.1016/bs.ctdb.2016.12.005

85. Filardo EJ. A role for G-protein coupled estrogen receptor (GPER) in estrogen-induced carcinogenesis: dysregulated glandular homeostasis, survival and metastasis. J Steroid Biochem Mol Biol. (2018) 176:38-48. doi: 10.1016/j.jsbmb.2017.05.005

86. Sun G, Porter W, Safe S. Estrogen-induced retinoic acid receptor alpha 1 gene expression: role of estrogen receptor-Sp1 complex. Mol Endocrinol. (1998) 12:882-90.

87. Liu MM, Albanese C, Anderson CM, Hilty K, Webb P, Uht RM, et al. Opposing action of estrogen receptors alpha and beta on cyclin D1 gene expression. J Biol Chem. (2002) 277:24353-60. doi: 10.1074/jbc.M2018 29200

88. Ray A, Prefontaine KE, Ray P. Down-modulation of interleukin-6 gene expression by 17 beta-estradiol in the absence of high affinity DNA binding by the estrogen receptor. J Biol Chem. (1994) 269:12940-6.

89. Folkerd EJ, Dowsett M. Influence of sex hormones on cancer progression. JClin Oncol. (2010) 28:4038-44. doi: 10.1200/JCO.2009.27.4290

90. Frasor J, Danes JM, Komm B, Chang KC, Lyttle CR, Katzenellenbogen BS. Profiling of estrogen up- and down-regulated gene expression in human breast cancer cells: insights into gene networks and pathways underlying estrogenic control of proliferation and cell phenotype. Endocrinology (2003) 144:4562-74. doi: 10.1210/en.2003-0567

91. Hershberger PA, Vasquez AC, Kanterewicz B, Land S, Siegfried JM, Nichols M. Regulation of endogenous gene expression in human non-small cell lung cancer cells by estrogen receptor ligands. Cancer Res. (2005) 65:1598-605. doi: 10.1158/0008-5472.CAN-04-2694

92. Sirianni R, Zolea F, Chimento A, Ruggiero C, Cerquetti L, Fallo F, et al. Targeting estrogen receptor-alpha reduces adrenocortical cancer (ACC) cell growth in vitro and in vivo: potential therapeutic role of selective estrogen receptor modulators (SERMs) for ACC treatment. J Clin Endocrinol Metab. (2012) 97:E2238-50. doi: 10.1210/jc.2012-2374

93. Yee D, Lee AV. Crosstalk between the insulin-like growth factors and estrogens in breast cancer. J Mammary Gland Biol Neoplasia (2000) 5:107-15. doi: 10.1023/A:1009575518338

94. Osborne CK, Shou J, Massarweh S, Schiff R. Crosstalk between estrogen receptor and growth factor receptor pathways as a cause for endocrine therapy resistance in breast cancer. Clin Cancer Res. (2005) 11:865s-70s. 
95. Ignatov A, Ignatov T, Roessner A, Costa SD, Kalinski T. Role of GPR30 in the mechanisms of tamoxifen resistance in breast cancer MCF-7 cells. Breast Cancer Res Treat. (2010) 123:87-96. doi: 10.1007/s10549-009-0624-6

96. McNamara KM, Sasano H. Beyond the C18 frontier: androgen and glucocorticoid metabolism in breast cancer tissues: the role of non-typical steroid hormones in breast cancer development and progression. Steroids (2015) 103:115-22. doi: 10.1016/j.steroids.2015.05.008

97. McNamara KM, Sasano H. Androgen and breast cancer: an update. Curr Opin Endocrinol Diab Obes. (2016) 23:249-56. doi: 10.1097/MED.0000000000000251

98. Hickey TE, Robinson JL, Carroll JS, Tilley WD. Minireview: the androgen receptor in breast tissues: growth inhibitor, tumor suppressor, oncogene? Mol Endocrinol. (2012) 26:1252-67. doi: 10.1210/me.2012-1107

99. Lim E, Tarulli G, Portman N, Hickey TE, Tilley WD, Palmieri C. Pushing estrogen receptor around in breast cancer. Endocrine-Related Cancer (2016) 23:T227-41. doi: 10.1530/ERC-16-0427

100. McNamara KM, Moore NL, Hickey TE, Sasano H, Tilley WD. Complexities of androgen receptor signalling in breast cancer. Endocr Related Cancer (2014) 21:T161-81. doi: 10.1530/ERC-14-0243

101. Feng J, Li L, Zhang N, Liu J, Zhang L, Gao H, et al. Androgen and AR contribute to breast cancer development and metastasis: an insight of mechanisms. Oncogene (2017) 36:2775-90. doi: 10.1038/onc.2016.432

102. Li Y, Wan X, Wei Y, Liu X, Lai W, Zhang L, et al. LSD1-mediated epigenetic modification contributes to ovarian cancer cell migration and invasion. Oncol Rep. (2016) 35:3586-92. doi: 10.3892/or.2016.4729

103. Ferrari-Amorotti G, Fragliasso V, Esteki R, Prudente Z, Soliera AR, Cattelani S, et al. Inhibiting interactions of lysine demethylase LSD1 with snail/slug blocks cancer cell invasion. Cancer Res. (2013) 73:235-45. doi: 10.1158/0008-5472.CAN-12-1739

104. Ye Q, Chung LW, Cinar B, Li S, Zhau HE. Identification and characterization of estrogen receptor variants in prostate cancer cell lines. J Steroid Biochem Mol Biol. (2000) 75:21-31. doi: 10.1016/S0960-0760(00)00118-7

105. Denmeade SR, Isaacs JT. Activation of programmed (apoptotic) cell death for the treatment of prostate cancer. Adv Pharmacol. (1996) 35:281-306. doi: 10.1016/S1054-3589(08)60278-1

106. Takezawa $\mathrm{Y}$, Izumi $\mathrm{K}$, Machioka $\mathrm{K}$, Iwamoto $\mathrm{H}$, Naito $\mathrm{R}$, Makino $\mathrm{T}$, et al. Crosstalk between androgen-sensitive and androgeninsensitive prostate cancer cells. Anticancer Res. (2018) 38:2045-55. doi: 10.21873/anticanres.12444

107. Yu T, Liu M, Luo H, Wu C, Tang X, Tang S, et al. GPER mediates enhanced cell viability and motility via non-genomic signaling induced by 17 betaestradiol in triple-negative breast cancer cells. J Steroid Biochem Mol Biol. (2014) 143:392-403. doi: 10.1016/j.jsbmb.2014.05.003

108. Steiman J, Peralta EA, Louis S, Kamel O. Biology of the estrogen receptor, GPR30, in triple negative breast cancer. Am J Surg. (2013) 206:698-703. doi: 10.1016/j.amjsurg.2013.07.014

109. Shen Y, Yang F, Zhang W, Song W, Liu Y, Guan X. The androgen receptor promotes cellular proliferation by suppression of g-protein coupled estrogen receptor signaling in triple-negative breast cancer. Cell Physiol Biochem. (2017) 43:2047-61. doi: 10.1159/000484187

110. Zhu A, Li Y, Song W, Xu Y, Yang F, Zhang W, et al. Antiproliferative effect of androgen receptor inhibition in mesenchymal stem-like triple-negative breast cancer. Cell Physiol Biochem. (2016) 38:1003-14. doi: $10.1159 / 000443052$

111. Chen ZJ, Wei W, Jiang GM, Liu H, Wei WD, Yang X, et al. Activation of GPER suppresses epithelial mesenchymal transition of triple negative breast cancer cells via NF-kappaB signals. Mol Oncol. (2016) 10:775-88. doi: 10.1016/j.molonc.2016.01.002

112. Bosland MC, Ford H, Horton L. Induction at high incidence of ductal prostate adenocarcinomas in NBL/Cr and Sprague-Dawley Hsd:SD rats treated with a combination of testosterone and estradiol17 beta or diethylstilbestrol. Carcinogenesis (1995) 16:1311-7. doi: 10.1093/carcin/16.6.1311

113. Ricke WA, McPherson SJ, Bianco JJ, Cunha GR, Wang Y, Risbridger GP. Prostatic hormonal carcinogenesis is mediated by in situ estrogen production and estrogen receptor alpha signaling. FASEB J. (2008) 22:1512-20. doi: 10.1096/fj.07-9526com
114. Bonkhoff H, Fixemer T, Hunsicker I, Remberger K. Estrogen receptor expression in prostate cancer and premalignant prostatic lesions. Am J Pathol. (1999) 155:641-7. doi: 10.1016/S0002-9440(10)65160-7

115. Fixemer T, Remberger K, Bonkhoff H. Differential expression of the estrogen receptor beta (ERbeta) in human prostate tissue, premalignant changes, and in primary, metastatic, and recurrent prostatic adenocarcinoma. Prostate (2003) 54:79-87. doi: 10.1002/pros.10171

116. Chan QK, Lam HM, Ng CF, Lee AY, Chan ES, Ng HK, et al. Activation of GPR30 inhibits the growth of prostate cancer cells through sustained activation of Erk1/2, c-jun/c-fos-dependent upregulation of p21, and induction of G(2) cell-cycle arrest. Cell Death Differentiation (2010) 17:1511-23. doi: 10.1038/cdd.2010.20

117. Liu J, Heikkila P, Meng QH, Kahri AI, Tikkanen MJ, Voutilainen R. Expression of low and high density lipoprotein receptor genes in human adrenals. Eur J Endocrinol. (2000) 142:677-82. doi: 10.1530/eje.0.1420677

118. Bochem AE, Holleboom AG, Romijn JA, Hoekstra M, Dallinga-Thie GM, Motazacker MM, et al. High density lipoprotein as a source of cholesterol for adrenal steroidogenesis: a study in individuals with low plasma HDL-C. J Lipid Res. (2013) 54:1698-704. doi: 10.1194/jlr.P033449

119. Chan S, Debono M. Replication of cortisol circadian rhythm: new advances in hydrocortisone replacement therapy. Ther Adv Endocrinol Metab. (2010) 1:129-38. doi: 10.1177/2042018810380214

120. Bohm M, Herrmann W, Wassmann S, Laufs U, Nickenig G. Does statin therapy influence steroid hormone synthesis? Zeitschrift Kardiologie (2004) 93:43-8. doi: 10.1007/s00392-004-1003-2

121. Clauss SB, Holmes KW, Hopkins P, Stein E, Cho M, Tate A et al. Efficacy and safety of lovastatin therapy in adolescent girls with heterozygous familial hypercholesterolemia. Pediatrics (2005) 116:682-8. doi: 10.1542/peds.2004-2090

122. Venkatesh B, Imeson L, Kruger P, Cohen J, Jones M, Bellomo R, et al. Elevated plasma-free cortisol concentrations and ratios are associated with increased mortality even in the presence of statin therapy in patients with severe sepsis. Crit Care Med. (2015) 43:630-5. doi: 10.1097/CCM.0000000000000750

123. Sahebkar A, Rathouska J, Simental-Mendia LE, Nachtigal P. Statin therapy and plasma cortisol concentrations: A systematic review and meta-analysis of randomized placebo-controlled trials. Pharmacol Res. (2016) 103:17-25. doi: 10.1016/j.phrs.2015.10.013

124. Schooling CM, Au Yeung SL, Freeman G, Cowling BJ The effect of statins on testosterone in men and women, a systematic review and meta-analysis of randomized controlled trials. BMC Med. (2013) 11:57. doi: 10.1186/1741-7015-11-57

125. Harshman LC, Wang X, Nakabayashi M, Xie W, Valenca L, Werner L, et al. Statin use at the time of initiation of androgen deprivation therapy and time to progression in patients with hormone-sensitive prostate cancer. JAMA Oncol. (2015) 1:495-504. doi: 10.1001/jamaoncol.2015.0829

126. Bennett NC, Hooper JD, Lambie D, Lee CS, Yang T, Vesey DA, et al. Evidence for steroidogenic potential in human prostate cell lines and tissues. Am J Pathol. (2012) 181:1078-87. doi: 10.1016/j.ajpath.2012.06.009

127. Hu J, La Vecchia C, de Groh M, Negri E, Morrison H, Mery L, et al. Dietary cholesterol intake and cancer. Ann Oncol. (2012) 23:491-500. doi: 10.1093/annonc/mdr155

128. Swan R, Alnabulsi A, Cash B, Alnabulsi A, Murray GI. Characterisation of the oxysterol metabolising enzyme pathway in mismatch repair proficient and deficient colorectal cancer. Oncotarget (2016) 7:46509-27. doi: 10.18632/oncotarget.10224

129. Nagano K, Imai S, Zhao X, Yamashita $T$, Yoshioka $Y$, Abe $Y$, et al. Identification and evaluation of metastasis-related proteins, oxysterol binding protein-like 5 and calumenin, in lung tumors. Int J Oncol. (2015) 47:195-203. doi: 10.3892/ijo.2015.3000

130. Nelson ER, Wardell SE, Jasper JS, Park S, Suchindran S, Howe MK, et al. 27-Hydroxycholesterol links hypercholesterolemia and breast cancer pathophysiology. Science (2013) 342:1094-8. doi: 10.1126/science.1241908

131. Wu Q, Ishikawa T, Sirianni R, Tang H, McDonald JG, Yuhanna IS, et al. 27Hydroxycholesterol promotes cell-autonomous, ER-positive breast cancer growth. Cell Rep. (2013) 5:637-45. doi: 10.1016/j.celrep.2013.10.006

132. Tian W, Pang W, Ge Y, He X, Wang D, Li X, et al. Hepatocytegenerated 27-hydroxycholesterol promotes the growth of melanoma by 
activation of estrogen receptor alpha. J Cell Biochem. (2018) 119:2929-38. doi: $10.1002 /$ jcb. 26498

133. Raza S, Meyer M, Goodyear CK, Hammer DP, Guo B, Ghribi O. The cholesterol metabolite 27-hydroxycholesterol stimulates cell proliferation via ERbeta in prostate cancer cells. Cancer Cell Int. (2017) 17:52. doi: 10.1186/s12935-017-0422-x

134. Loilome W, Wechagama P, Namwat N, Jusakul A, Sripa B, Miwa M, et al. Expression of oxysterol binding protein isoforms in opisthorchiasisassociated cholangiocarcinoma: a potential molecular marker for tumor metastasis. Parasitol Int. (2012) 61:136-9. doi: 10.1016/j.parint.2011.07.003

135. Umetani M, Shaul PW. 27-Hydroxycholesterol: the first identified endogenous SERM Trends Endocrinol Metab: (2011) 22:130-5. doi: 10.1016/j.tem.2011.01.003

136. Lappano R, Recchia AG, De Francesco EM, Angelone T, Cerra MC, Picard D, et al. The cholesterol metabolite 25-hydroxycholesterol activates estrogen receptor alpha-mediated signaling in cancer cells and in cardiomyocytes. PLoS ONE (2011) 6:e16631. doi: 10.1371/journal.pone.0016631

137. Simigdala N, Gao Q, Pancholi S, Roberg-Larsen H, Zvelebil M, Ribas R, et al. Cholesterol biosynthesis pathway as a novel mechanism of resistance to estrogen deprivation in estrogen receptor-positive breast cancer. Breast Cancer Res. (2016) 18:58. doi: 10.1186/s13058-016-0713-5

138. Dalenc F, Iuliano L, Filleron T, Zerbinati C, Voisin M, Arellano C, et al. Circulating oxysterol metabolites as potential new surrogate markers in patients with hormone receptor-positive breast cancer: results of the OXYTAM study. J Steroid Biochem Mol Biol. (2017) 169:210-8. doi: 10.1016/j.jsbmb.2016.06.010

139. Raychaudhuri S, Im YJ, Hurley JH, Prinz WA. Nonvesicular sterol movement from plasma membrane to ER requires oxysterol-binding protein-related proteins and phosphoinositides. J Cell Biol. (2006) 173:107-19. doi: $10.1083 /$ jcb. 200510084

140. Wang PY, Weng J, Anderson RG. OSBP is a cholesterol-regulated scaffolding protein in control of ERK 1/2 activation. Science (2005) 307:1472-6. doi: $10.1126 /$ science. 1107710

141. Charman M, Colbourne TR, Pietrangelo A, Kreplak L, Ridgway ND. Oxysterol-binding protein (OSBP)-related protein 4 (ORP4) is essential for cell proliferation and survival. J Biol Chem. (2014) 289:15705-17. doi: 10.1074/jbc.M114.571216

142. Li JW, Xiao YL, Lai CF, Lou N, Ma HL, Zhu BY, et al. Oxysterolbinding protein-related protein $4 \mathrm{~L}$ promotes cell proliferation by sustaining intracellular $\mathrm{Ca} 2+$ homeostasis in cervical carcinoma cell lines. Oncotarget (2016) 7:65849-61. doi: 10.18632/oncotarget.11671

143. Burgett AW, Poulsen TB, Wangkanont K, Anderson DR, Kikuchi C, Shimada $\mathrm{K}$, et al. Natural products reveal cancer cell dependence on oxysterol-binding proteins. Nat Chem Biol. (2011) 7:639-47. doi: $10.1038 /$ nchembio. 625

144. Kimbung S, Chang CY, Bendahl PO, Dubois L, Thompson JW, McDonnell DP, et al. Impact of 27-hydroxylase (CYP27A1) and 27hydroxycholesterol in breast cancer. Endocr Related Cancer (2017) 24:339-49. doi: 10.1530/ERC-16-0533

145. Nguyen VT, Barozzi I, Faronato M, Lombardo Y, Steel JH, Patel N, et al. Differential epigenetic reprogramming in response to specific endocrine therapies promotes cholesterol biosynthesis and cellular invasion. Nat Commun. (2015) 6:10044. doi: 10.1038/ncomms10044

146. Murtola TJ, Tammela TL, Maattanen L, Hakama M, Auvinen A. Prostate cancer risk among users of finasteride and alpha-blockers a population based case-control study. Eur J Cancer (2007) 43:775-81. doi: 10.1016/j.ejca.2006.12.001

147. Shannon J, Tewoderos S, Garzotto M, Beer TM, Derenick R, Palma A, et al. Statins and prostate cancer risk: a case-control study. Am J Epidemiol. (2005) 162:318-25. doi: 10.1093/aje/kwi203

148. Jacobs EJ, Rodriguez C, Bain EB, Wang Y, Thun MJ, Calle EE. Cholesterollowering drugs and advanced prostate cancer incidence in a large U.S. cohort. Cancer Epidemiol Biomarkers Prevent. (2007) 16:2213-7. doi: 10.1158/1055-9965.EPI-07-0448

149. Brown M, Hart C, Tawadros T, Ramani V, Sangar V, Lau M, et al. The differential effects of statins on the metastatic behaviour of prostate cancer. Br J Cancer (2012) 106:1689-96. doi: 10.1038/bjc.2012.138
150. Heaney RP. Vitamin D in health and disease. Clin J Am Soc Nephrol. (2008) 3:1535-41. doi: 10.2215/CJN.01160308

151. Japelt RB, Jakobsen J. Vitamin D in plants: a review of occurrence, analysis, and biosynthesis. Front Plant Sci. (2013) 4:136. doi: 10.3389/fpls.2013.00136

152. Jones G, Prosser DE, Kaufmann M. Cytochrome P450-mediated metabolism of vitamin D. J Lipid Res. (2014) 55:13-31. doi: 10.1194/jlr.R031534

153. Hobaus J, Thiem U, Hummel DM, Kallay E. Role of calcium, vitamin D, and the extrarenal vitamin D hydroxylases in carcinogenesis. Anti Cancer Agents Med Chem. (2013) 13:20-35. doi: 10.2174/187152013804487434

154. Jeon SM, Shin EA. Exploring vitamin D metabolism and function in cancer. Exp Mol Med. (2018) 50:20. doi: 10.1038/s12276-018-0038-9

155. Slominski AT, Brozyna AA, Skobowiat C, Zmijewski MA, Kim TK, Janjetovic $\mathrm{Z}$, et al. On the role of classical and novel forms of vitamin D in melanoma progression and management. J Steroid Biochem Mol Biol. (2018) 177:159-70. doi: 10.1016/j.jsbmb.2017.06.013

156. Grant WB. A review of the evidence supporting the vitamin Dcancer prevention hypothesis in 2017. Anticancer Res. (2018) 38:1121-36. doi: 10.21873/anticanres. 12331

157. Castronovo C, Castronovo V, Nikkels A, Peulen O. Vitamin D anti-cancer activities: observations, doubts and certainties. Revue Medicale Liege (2015) 70:495-500.

158. Ahonen MH, Tenkanen L, Teppo L, Hakama M, Tuohimaa P. Prostate cancer risk and prediagnostic serum 25-hydroxyvitamin D levels (Finland). Cancer Causes Control (2000) 11:847-52. doi: 10.1023/A:1008923802001

159. Schwartz GG. Vitamin D and the epidemiology of prostate cancer. Semin Dialysis (2005) 18:276-89. doi: 10.1111/j.1525-139X.2005.18403.x

160. Moreno J, Krishnan AV, Feldman D. Molecular mechanisms mediating the anti-proliferative effects of Vitamin D in prostate cancer. J Steroid Biochem Mol Biol. (2005) 97:31-6. doi: 10.1016/j.jsbmb.2005.06.012

161. Simboli-Campbell M, Narvaez CJ, van Weelden K, Tenniswood M, Welsh J. Comparative effects of 1,25(OH)2D3 and EB1089 on cell cycle kinetics and apoptosis in MCF-7 breast cancer cells. Breast Cancer Res Treat. (1997) 42:31-41. doi: 10.1023/A:1005772432465

162. James SY, Mackay AG, Colston KW. Effects of 1,25 dihydroxyvitamin D3 and its analogues on induction of apoptosis in breast cancer cells. J Steroid Biochem Mol Biol. (1996) 58:395-401. doi: 10.1016/0960-0760(96)00048-9

163. James SY, Mackay AG, Binderup L, Colston KW. Effects of a new synthetic vitamin D analogue, EB1089, on the oestrogen-responsive growth of human breast cancer cells. J Endocrinol. (1994) 141:555-63. doi: 10.1677 /joe.0.1410555

164. Krishnan AV, Swami S, Peng L, Wang J, Moreno J, Feldman D. Tissue-selective regulation of aromatase expression by calcitriol: implications for breast cancer therapy. Endocrinology (2010) 151:32-42. doi: 10.1210/en.2009-0855

165. Scaglione-Sewell BA, Bissonnette M, Skarosi S, Abraham C, Brasitus TA. A vitamin D3 analog induces a G1-phase arrest in CaCo-2 cells by inhibiting cdk2 and cdk6: roles of cyclin E, p21Waf1, and p27Kip1. Endocrinology (2000) 141:3931-9. doi: 10.1210/endo.141.11.7782

166. Diaz GD, Paraskeva C, Thomas MG, Binderup L, Hague A. Apoptosis is induced by the active metabolite of vitamin D3 and its analogue EB1089 in colorectal adenoma and carcinoma cells: possible implications for prevention and therapy. Cancer Res. (2000) 60:2304-12.

167. Bises G, Kallay E, Weiland T, Wrba F, Wenzl E, Bonner E, et al. 25hydroxyvitamin D3-1alpha-hydroxylase expression in normal and malignant human colon. J Histochem Cytochem. (2004) 52:985-9. doi: 10.1369/jhc.4B6271.2004

168. Tangpricha V, Flanagan JN, Whitlatch LW, Tseng CC, Chen TC, Holt PR, et al. 25-hydroxyvitamin D-1alpha-hydroxylase in normal and malignant colon tissue. Lancet (2001) 357:1673-4. doi: 10.1016/S0140-6736(00)04831-5

169. Shabahang M, Buras RR, Davoodi F, Schumaker LM, Nauta RJ, Evans SR. 1,25-Dihydroxyvitamin D3 receptor as a marker of human colon carcinoma cell line differentiation and growth inhibition. Cancer Res. (1993) 53:3712-8.

170. Sheinin Y, Kaserer K, Wrba F, Wenzl E, Kriwanek S, Peterlik M, et al. In situ mRNA hybridization analysis and immunolocalization of the vitamin D receptor in normal and carcinomatous human colonic mucosa: relation to epidermal growth factor receptor expression. Virchows Archiv Int J Pathol. (2000) 437:501-7. doi: 10.1007/s004280000275 
171. Cross HS, Bareis P, Hofer H, Bischof MG, Bajna E, Kriwanek S, et al. 25-Hydroxyvitamin D3-1 $\alpha$-hydroxylase and vitamin D receptor gene expression in human colonic mucosa is elevated during early cancerogenesis. Steroids (2001) 66:287-92. doi: 10.1016/S0039-128X(00)00153-7

172. Marshall TG. Are statins analogues of vitamin D? Lancet (2006) 368:1234; author reply 1235. doi: 10.1016/S0140-6736(06)69509-3

173. Horkko TT, Tuppurainen K, George SM, Jernvall P, Karttunen TJ, Makinen MJ. Thyroid hormone receptor betal in normal colon and colorectal cancerassociation with differentiation, polypoid growth type and K-ras mutations. Int J Cancer (2006) 118:1653-9. doi: 10.1002/ijc.21556

174. Horvath HC, Lakatos P, Kosa JP, Bacsi K, Borka K, Bises G, et al. The candidate oncogene CYP24A1: A potential biomarker for colorectal tumorigenesis. J Histochem Cytochem. (2010) 58:277-85. doi: 10.1369/jhc.2009.954339

175. Pilon C, Urbanet R, Williams TA, Maekawa T, Vettore S, Sirianni R, et al. 1alpha,25-Dihydroxyvitamin $\mathrm{D}(3)$ inhibits the human H295R cell proliferation by cell cycle arrest: a model for a protective role of vitamin D receptor against adrenocortical cancer. J Steroid Biochem Mol Biol. (2014) 140:26-33. doi: 10.1016/j.jsbmb.2013.11.008

176. Sahebkar A, Reiner Z, Simental-Mendia LE, Ferretti G, Della Corte C, Nobili V. Impact of statin therapy on plasma vitamin D levels: a systematic review and meta-analysis. Curr Pharmaceut Design (2017) 23:861-9. doi: 10.2174/1381612822666161006150542

177. Mazidi M, Rezaie P, Vatanparast H, Kengne AP. Effect of statins on serum vitamin D concentrations: a systematic review and meta-analysis. Eur J Clin Investig. (2017) 47:93-101. doi: 10.1111/eci.12698

178. Wilczek H, Sobra J, Justova V, Ceska R, Juzova Z, Prochazkova R, et al. [Iatropathogenic effect of Mevacor on vitamin D metabolism]. Casopis Lekaru Ceskych (1989) 128:1254-6.

179. Wilczek H, Sobra J, Ceska R, Justova V, Juzova Z, Prochazkova R, et al. [Monitoring plasma levels of vitamin D metabolites in simvastatin (Zocor) therapy in patients with familial hypercholesterolemia]. Casopis Lekaru Ceskych (1994) 133:727-9.

180. Perez-Castrillon JL, Vega G, Abad L, Sanz A, Chaves J, Hernandez $\mathrm{G}$, et al. Effects of atorvastatin on vitamin $\mathrm{D}$ levels in patients with acute ischemic heart disease. Am J Cardiol. (2007) 99:903-5. doi: 10.1016/j.amjcard.2006.11.036

181. Yavuz B, Ertugrul DT, Cil H, Ata N, Akin KO, Yalcin AA, et al. Increased levels of 25 hydroxyvitamin D and 1,25-dihydroxyvitamin D after rosuvastatin treatment: a novel pleiotropic effect of statins? Cardiovasc Drugs Ther. (2009) 23:295-9. doi: 10.1007/s10557-009-6181-8

182. Ertugrul DT, Yavuz B, Cil H, Ata N, Akin KO, Kucukazman M, et al. STATIND study: comparison of the influences of rosuvastatin and fluvastatin treatment on the levels of 25 hydroxyvitamin D. Cardiovasc Therapeut. (2011) 29:146-52. doi: 10.1111/j.1755-5922.2010.00141.x

183. Agarwal B, Bhendwal S, Halmos B, Moss SF, Ramey WG, Holt PR. Lovastatin augments apoptosis induced by chemotherapeutic agents in colon cancer cells. Clin Cancer Res. (1999) 5:2223-9.

184. Wachtershauser A, Akoglu B, Stein J. HMG-CoA reductase inhibitor mevastatin enhances the growth inhibitory effect of butyrate in the colorectal carcinoma cell line Caco-2. Carcinogenesis (2001) 22:1061-7. doi: $10.1093 /$ carcin/22.7.1061

185. Poynter JN, Gruber SB, Higgins PD, Almog R, Bonner JD, Rennert HS, et al. Statins and the risk of colorectal cancer. New Engl J Med. (2005) 352:2184-92. doi: 10.1056/NEJMoa043792

186. Giguere V, Yang N, Segui P, Evans RM. Identification of a new class of steroid hormone receptors. Nature (1988) 331:91-4. doi: 10.1038/331091a0

187. Wei W, Schwaid AG, Wang X, Wang X, Chen S, Chu Q, et al. Ligand activation of ERRalpha by cholesterol mediates statin and bisphosphonate effects. Cell Metab. (2016) 23:479-91. doi: 10.1016/j.cmet.2015.12.010

188. Vanacker JM, Pettersson K, Gustafsson JA, Laudet V. Transcriptional targets shared by estrogen receptor- related receptors (ERRs) and estrogen receptor (ER) alpha, but not by ERbeta. EMBO J. (1999) 18:4270-9. doi: 10.1093/emboj/18.15.4270

189. Zhang Z, Teng CT. Estrogen receptor alpha and estrogen receptor-related receptor alphal compete for binding and coactivator. Mol Cell Endocrinol. (2001) 172:223-33. doi: 10.1016/S0303-7207(00)00372-5

190. Gallet M, Vanacker JM. ERR receptors as potential targets in osteoporosis. Trends Endocrinol Metab. (2010) 21:637-41. doi: 10.1016/j.tem.2010.06.008

191. LaBarge S, McDonald M, Smith-Powell L, Auwerx J, Huss JM. Estrogenrelated receptor-alpha (ERRalpha) deficiency in skeletal muscle impairs regeneration in response to injury. FASEB J. (2014) 28:1082-97. doi: 10.1096/fj.13-229211

192. Wu F, Wang J, Wang Y, Kwok TT, Kong SK, Wong C. Estrogen-related receptor alpha (ERRalpha) inverse agonist XCT-790 induces cell death in chemotherapeutic resistant cancer cells. Chemico Biol Interact. (2009) 181:236-42. doi: 10.1016/j.cbi.2009.05.008

193. Casaburi I, Avena P, De Luca A, Chimento A, Sirianni R, Malivindi R, et al. Estrogen related receptor alpha (ERRalpha) a promising target for the therapy of adrenocortical carcinoma (ACC). Oncotarget (2015) 6:25135-48. doi: 10.18632/oncotarget. 4722

194. Duellman SJ, Calaoagan JM, Sato BG, Fine R, Klebansky B, Chao WR, et al. A novel steroidal inhibitor of estrogen-related receptor alpha (ERR alpha). Biochem Pharmacol. (2010) 80:819-26. doi: 10.1016/j.bcp.2010.05.024

195. Patch RJ, Searle LL, Kim AJ, De D, Zhu X, Askari HB, et al. Identification of diaryl ether-based ligands for estrogen-related receptor alpha as potential antidiabetic agents. J Med Chem. (2011) 54:788-808. doi: 10.1021/jm1 $01063 \mathrm{~h}$

Conflict of Interest Statement: The authors declare that the research was conducted in the absence of any commercial or financial relationships that could be construed as a potential conflict of interest.

Copyright (C) 2019 Chimento, Casaburi, Avena, Trotta, De Luca, Rago, Pezzi and Sirianni. This is an open-access article distributed under the terms of the Creative Commons Attribution License (CC BY). The use, distribution or reproduction in other forums is permitted, provided the original author(s) and the copyright owner(s) are credited and that the original publication in this journal is cited, in accordance with accepted academic practice. No use, distribution or reproduction is permitted which does not comply with these terms. 